نعالية برناهج تعويضى لتنهية مهارة التعاون للحد هن السلوك الاجتماكى العائي السلبى لدى أطفال الروضة قاطنى العشورائيات

فعالية برنامج تعويضى لتنمية مهارة التعاون للحد من السلوك الاجتماعى السلبى لاى أطفال الروضة قاطنى العشوائيات

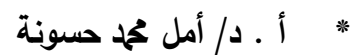

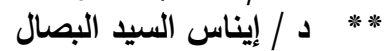

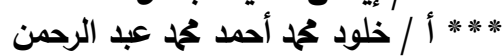

\section{هذص البحث}

هدفت الدراسة إلى التحقق من فعالية برنامج تعويضى لتنمية مهارة التعاون

للحد من السلوك الاجتماعى السلبى لدى أطفال الروضة قاطنى العشوائيات . اعتمدت الدراسة الحالية على المنهج شبه التجريبي ذو المجموعة التجريبية

$$
\text { الواحدة . }
$$

تقتصر العينة على (0 1) طفل وطفلة من أطفال المستوى الأول بالروضة ،

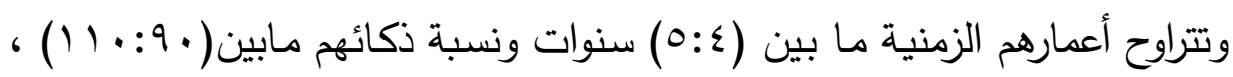
وقد روعـي في اختيـار العينـة التجـانس في العمـر العقلـي والزمنـي والمسـتوى

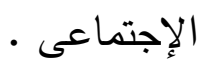
تكونت أدوات الدراسة من :

(اعداد الباحثة) بطاقة ملاحظة السلوك الاجتماعى السلبى. (إعداد الباحثة)

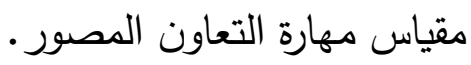
البرنامج التعويضى المقترح لأطفال الروضة قاطنى العشوائيات.(إعداد الباحثة)

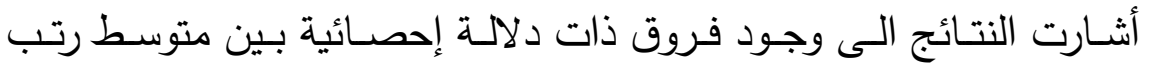
درجات المجموعة التجريبية في التطبيق القبلي والبعدي على مقياس مهارة التعاون المصور مما يدل على فعالية البرنامج التعويضى لتنمية مهارة التعاون للحد من السـوك الاجتمـاعى السـلبى لـدى أطفـال الروضــة قـاطنى العشـوائيات مـن أفراد المجموعة عينة الدراسة .

* أستاذ علم نفس الطفل " الصحة النفسية " وعميـ كلية ريـاض الأطفـال ورئيس قسم العلوم

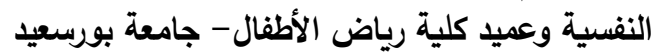

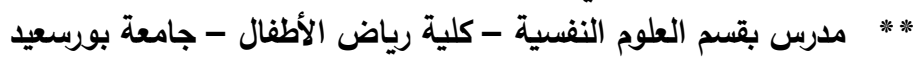

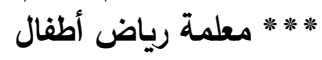




\section{المبلة العلمية لكلية رياض الأطفال س جامعة بوروسعيد}

\section{Abstract}

This study aimed to find out the Impact of the brain gym strategy in improving some of the academic and social skills of kindergarten children with attention deficit hyperactivity disorder.

The sample of the study consisted of (12) children from the kindergarten children with attention deficit hyperactivity disorder chosen from the city of Jeddah in Saudi Arabia, and randomly equally assigned into two groups, the control group $(n=6)$ which was regularly studied and experimental group $(n=6)$ studied upon the brain sport strategy.

Results showed statistically significant differences on academic and social skills on the telemetric for the experimental group scale, also results showed no differences on the performance of the experimental group between the telemetric monitoring, and the existence of differences in the total score on the academic and social skills due to sex variable in favor 


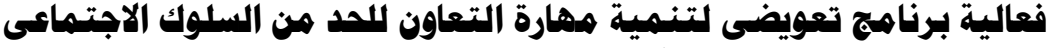 السلبى لدى أطفال الروضة قاطنى العشوائيات}

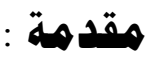

يعد الاهتمام بالطفولة عموماً ، وبالطفولة المبكرة على وجه الخصوص :

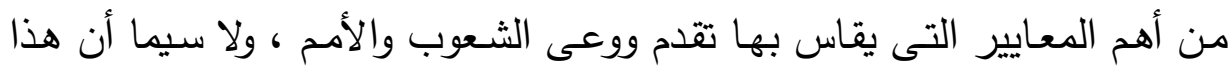

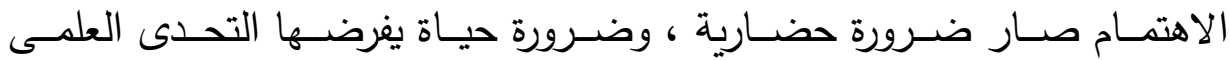

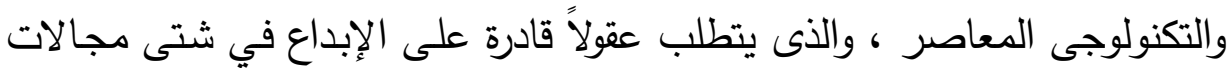

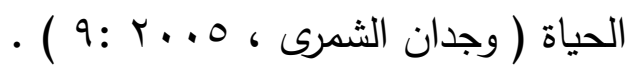

وتساعد الخبرات الاجتماعية التي تقدمها الروضـة لأطفالها علي تمثيل

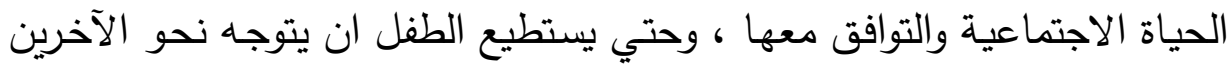
ويتعاطف معهم ليقيم علاقات اجتماعية سوية مع الاقران والراشدين ، يحتاج الي الي الئي

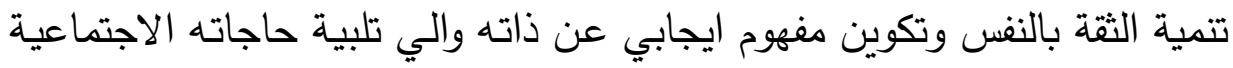
الاساسية ، والثـعور بالاطمئنسان الي أنـه مقبول مـن الآخرين وجدير بالتقدير

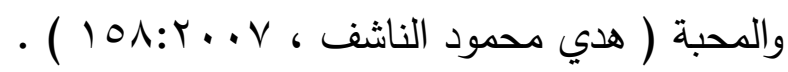

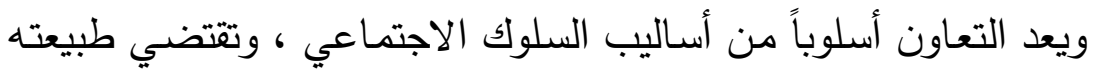

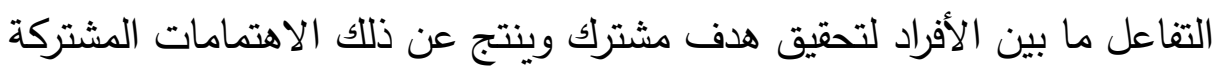
بينهم وروح الصداقة ، ومشاعر السعادة ، وزيادة الاتصال ، وتبادل المساعدة ،

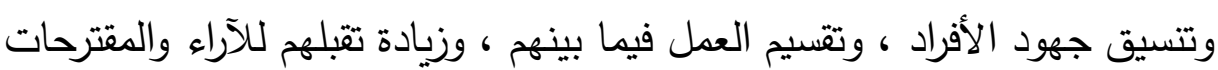
المتبادلة بينهم ، والاتفاق في الآراء ، وانخفاض معدل القلق في الجماعة ،

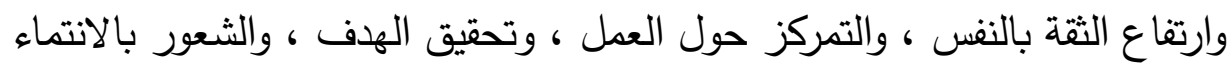

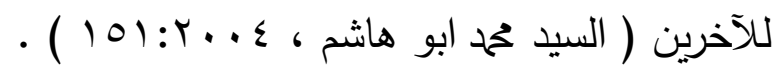

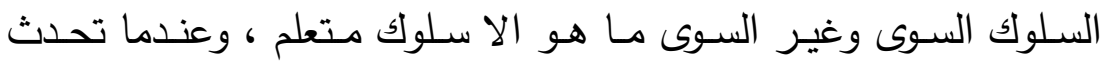
العلاقات الوظيفية بين المثير والاستجابة يحدث التعلم، ويتضح أن الطفل يتعلم

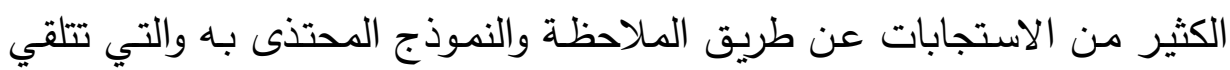
التعزيز والإثابة لأنواع السلوك المرغوب ولذا فالسلوك محكوم بنتائجه .

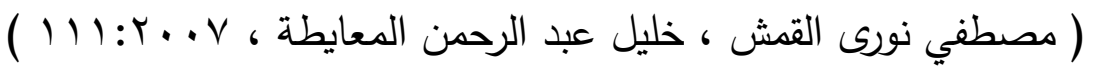


خلال فترة قصيرة زادت العشوائيات وجارت على مساحات من الأراضى الزراعية بشكل غير قانوني وبنيت بلا تخطيط ( فيروز كراوية ، بع : 1) (1) ) واتسمت الأسر في المناطق العشوائية بمجموعة من الملامس والسمات التي تعبر عن طبيعة الحياة الاجتماعية التي تعيشها الأسر في تلك المناطق منها التفكك الأسـري ، وانحـلال بنـاء الأدوار الاجتماعيـة ( مصــفى محمـود مصــفى ، ع 1 • Y: (9 ) ) ، وأثارت دراسة منال عبد الفتاح الهنيدي أنه لا يوجد وعي ثثافي

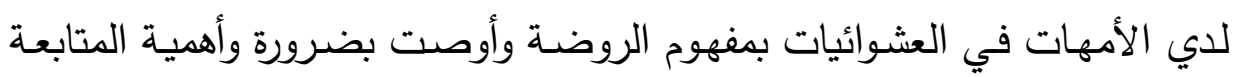

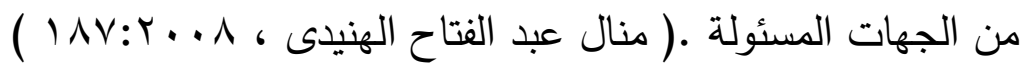
وتعانى غالبية المناطق العشوائية من ضـف الكيان الاجتماعي للأسر

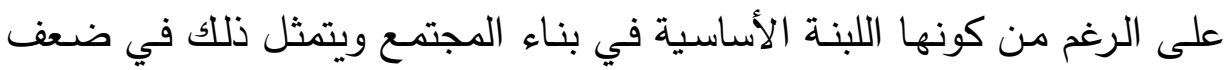

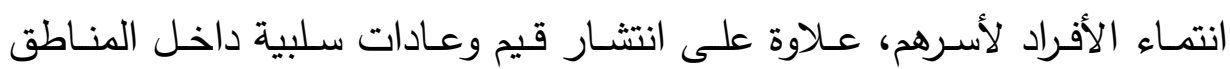
العشوائية تختلف عما هو سائد في المجتمع بوجه عام •

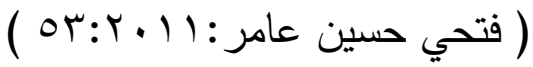

مما لاشك فيه أن هذه الفئة من الأطفال تحتاج إلى إعداد برامج تعويضية

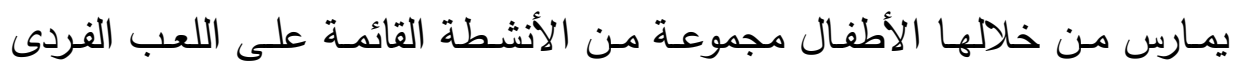
والجمـاعى ليكتسب الأطفـال منهـا الكثير مـن المفـاهيم والمهارات والسـوكيات ، وتتميـة قـدرات التعـاون وإكسـابهم العديــــــن الاتجاهـات الإيجابيـة والتوافـق الاجتماعى مع أنفسهم ومع الآخرين .

\section{هشكلة الدراسة : مشكئ}

لوحظ افتقار أطفال الروضة قاطنى العشوائيات لمهارة التعاون الضرورية لتحقيق سلوك اجتماعى إيجابى منهم ويرجع وذللك لعدة مظاهر من اهمها : • قلة سلوكيات المشاركة الاجتماعية بين الطفل والمحيطين به . زيادة التفاعل السلبي بين الأطفال . تدني مشاركة الأطفال في الانشطة التي تمارس في الروضة . 
فعالية برناهم تعويضى لتنهية ههارة التعاون اللد هن السلوك الاجتهاءى

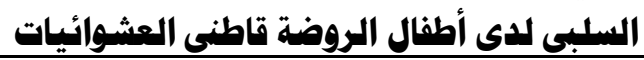

وبنـاءً على ماسبق ذكره توصلت الدارسـة الى وجود بعض القصور فى في

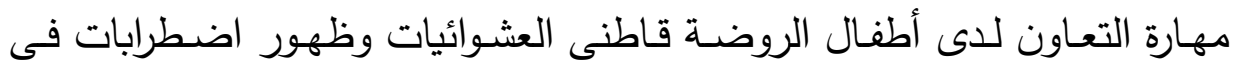

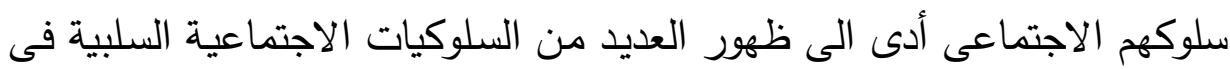

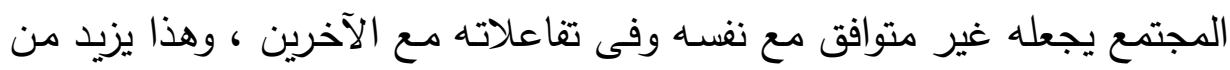

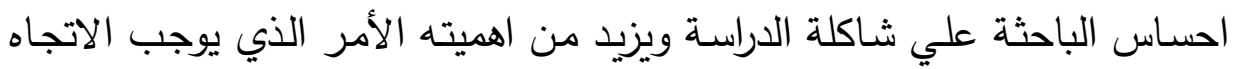
نحو هذه المشكلة ومحاولة حلها .

وفي ضوs ها سبق يمكن تحديد هشكلة الدراسة في التساؤل الرئيس التالي:

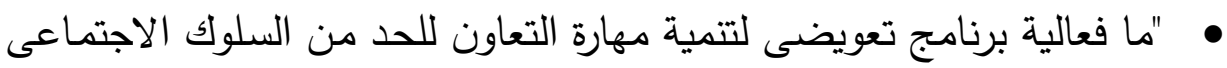

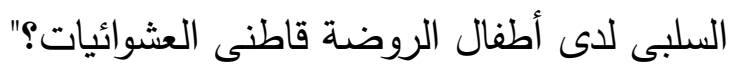

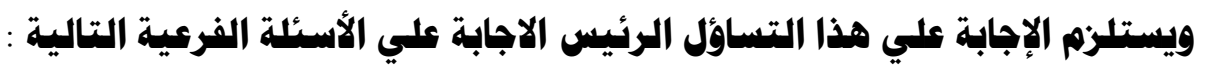

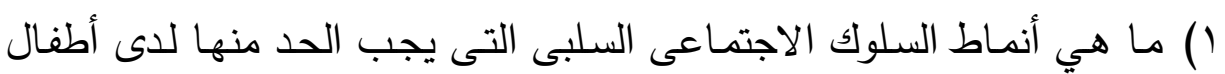

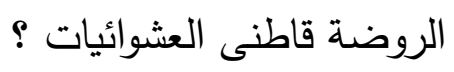

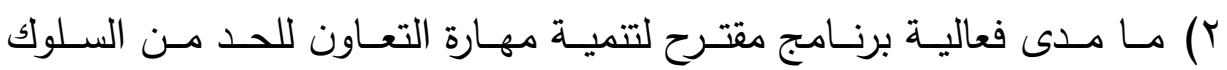

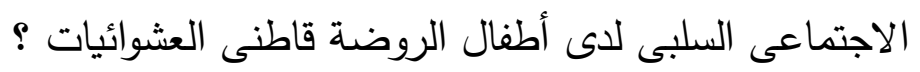

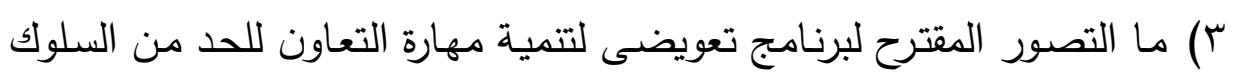
الاجتماعى السلبى لدى أطفال الروضة قاطنى العشوائيات ؟

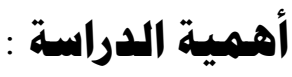 \\ الأهميـية النظرية النرابه :}

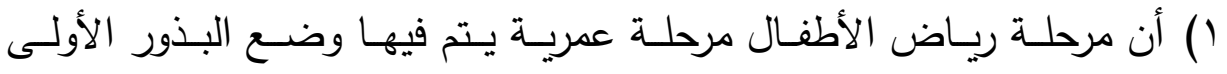

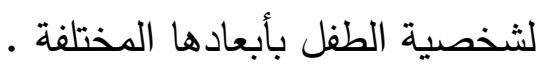

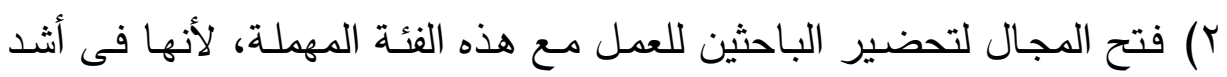

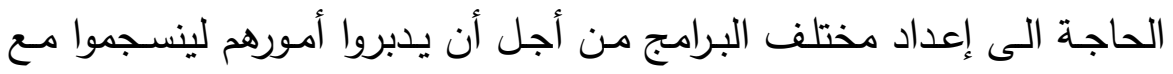

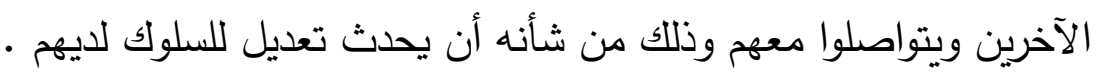

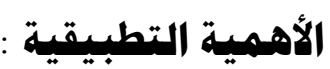
() امكانية التعرف على بعض أنماط السلوك الاجتماعى السلبى التى يقوم بها

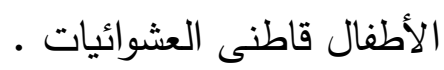


r) اكساب الطفل العديد من الإتجاهات والقيم الإيجابية المقبولة اجتماعياً .

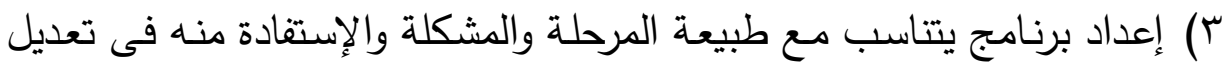
الأنماط السلبية لدى هؤلاء الأطفال وهذه الفئة .

\section{أهداف الدراسة :}

\section{هدفت الدراسة الحالية إلى :-}

( ) الحد من السلوك الاجتماعى السلبى لدى أطفال الرياض قاطنى العشوائيات.

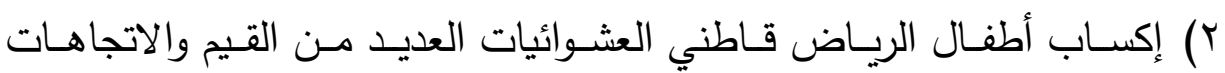

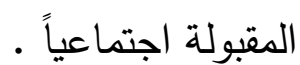

r) تتمية مهارة التعاون لدى أطفال الرياض قاطنى العشوائيات . حدود الدراسة : هـــدود بشـــــرية: عينـة عشـوائية مـن أطفــال الريـاض قـاطنى العشـوائيات

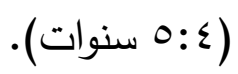

حدود مكانية : روضة مدرسة المسجد الأقصى الابتدائية بمحافظة بورسعيد .

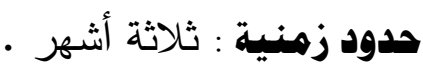
هصطات الدراسة :

\section{Compensating Program : البرناهج التعويضى}

تعرف الباحثة البرنامج التعويضى بأنه مخطط منظم في ضوء أسس علمية وتربوية لتقديم مجموعة من الأنشطة والتدريبات بشكل جماعي لتعويض بـ ليض أطفال العينة عن جوانب القصور فى مهارة التعاون من خلال عدد من الجلسات للحد من السلوك الاجتماعى السلبى لديهم • Cooperation : التعاون هو درجة قدرة الطفل على مساعدة الآخرين من جماعته العمرية فى حالة

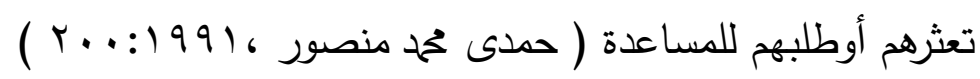
السلوك الاجتهاعى السبى : Negative social behavior بأنه السلوك الثاذ الذى يخالف سلوك معظم الناس داخل المجتمع الواحد، ولكى نعتبر أن السلوك سلبى غير سوى يجب أن يتسم هذا السلوك بالاستمرارية 
أو التكرار ، وأن يمكن ملاحظته والتعرف عليه مباشـرة من خـلال ردود الأفعـال تجـاه المؤثرات ، أو مـن خـلال عدم القدرة على التكيف الحسن مـع المجتمـح أو

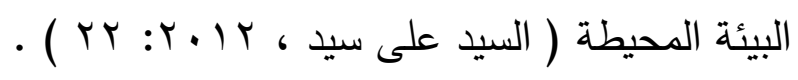

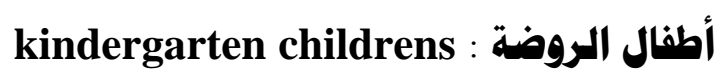

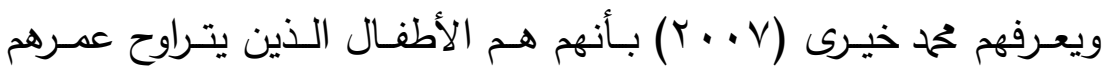

الزمني من سن (ع - 7) سنوات السن الذي يسبق سن التعليم الإلزامي وتخصص

ل kg1- kg2 ل فم فصول تسمى بفصول رياض الأطفال

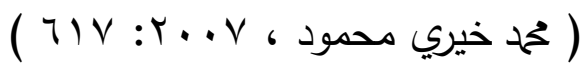

الأساليسب الإهصائية

باستخدام حزمة البرامج الإحصائية للعلوم الاجتماعية (spss)

Wilcoxon Test اختبار ويلكوكسون اللابارامتري ل) pearson correlation coefficient formula • طريقة بيرسون

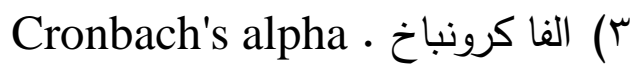

الإطار النظري والدراسات السابقة :

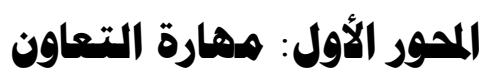

يعرف حسين الدريني التعاون بأنـه الموقف الذى تكون فيه العلاقة بين

تحقيق الفرد والآخرين علاقة موجبة ، ويبدأ اكتساب الطفل لتلك المهارة من خلال مواقف اللعب التعاوني والذى يظهر عادة فى نهاية السنة الثالثة وعادة ما يميل الطفل للعب مع طفل اخر ثم اللعب مع اكثر من طفل •

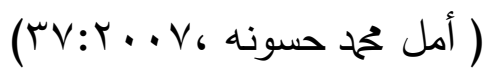

ويقصد بالتعاون الاجتماعى المهارة فى مساعدة ومعاونة الزملاء والأقران فى مواقف الحيـاة الاجتماعيـة والاشـتراك معهم فى الأنشطة الجماعيـة لإنجـاز عمل ما • (Merrell,1998,65) فالتدريب علي المهارات الاجتماعية لاكتساب السلوك الاجتماعي الفعال

يساعد علي زيادة الثقة بالنفس وتقليل مشاعر الخسارة وتقليل الاعتمادية . (Abate \& Milan, 1985,326) 
فمن خلال المهارات الاجتماعية يمكن تعليم الأطفال الذين يظهرون ردود افعال تتعلق بالغضب أثناء اللعب يتعلمون قواعد المشاركة والتعاون وكثيرا من الانشطة الأخرى التي تتعلق بالمهارات الاجتماعية ـ (Varma , 1997:26) استزاتيجيات اكتساب المهارات الاجتماعية:(ههارة التعاون)

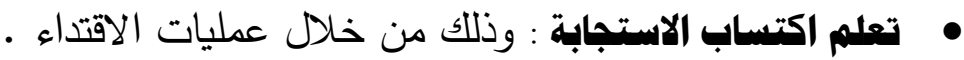
• إعـادة اصسـدار الاســتجابة : وذلك باستخدام أسـاليب تمثيل الدور أوالتكرار

$$
\text { أوالتسميع أوالتدريب الذاتى • }
$$

أحكـام الاسـتجابة : من خـلال تقييم سلوك المتدرب وإخباره بجوانب ضعفه

$$
\text { وقوته ، تقديم دعم حين يستجيب الفرد لهذا التقييم • }
$$

إعادة تشكيل البنية المعرفيسة : من خلال توضيح الجوانب المعرفية المعوقة مثل المعتقدات غير المنطقيـة والعبارات الداخلية السلبية ، ودعوة المتدرب لدحض تلك المعتقدات وإحـلال أخرى منطقيـة بـلا منهـا وإصدار عبارات داخلية إيجابية ـ

• انتقسال الاسـتجابة : فمن أهم شروط نجاح برامج تعديل السلوك تتمثل فى الحاجة الى انتقال أثر التدريب الى بيئة الحياة الواقعية . ) ( طريف شوقى غريب ، Y (991)

فنيات التدريب على المهارات الاجتهماعية ( ههارة التعاون ) • النسمذجة Modeling : وفيها يقوم فرد اخر بأداء المهارة كنموذج. • لعب العدور Role Playing : حيث يطلب المدرب من المتدربين القيام بأداء المهارة المطلوبة كما شاهدوها . • التفذيـة الراجعـة Feed Back : حيث يتلقي المتدرب التعليمات عن طريقة اداءه من المشاهدين وكذلك من المدرب وهو تعزيز اجتماعي للأداء الجيد . • تعريـــ Promotion : وهـو زيـادة وتقويـة السـلوك نتيجـة لمـا يقع بعده مـن

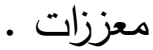




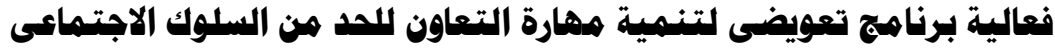 السبى لدى أطفال الروضة قاطنى العشوائيات}

انتقـال اثر التسدريب Transfer of Training : حيث يطلب المدرب من : المتدربين اداء المهارة التي تدربوا عليها خارج نطاق جلسة التدريب كواجب منزلي علي ان يناقش قيامهم بذلك في بداية الجلسة القادمة نع تقديم التشجيع الملائم لمن اتم الواجب المنزلي كما ينبغي •

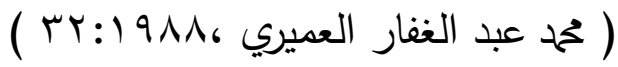

اظهرت نتائج بحث حسام عباس سـلام (1) (1) ان ممارسـة الانشطة العلمية التى يتضمنها البرنامج أتاحت الفرصة للأطفال للتعاون والتفاعل الإيجابى بينهم وكذلك أتاحت الفرصة لممارسة العمل واللعب الجماعى مما أدى الى تتمية بعض المهارات الاجتماعية وتتمية مهارات العمل واللعب الجماعى ومن خـلا ملاحظة الباحث للأطفال وتوجيهم لإتباع أنماط السلوك الاجتماعى السليم .

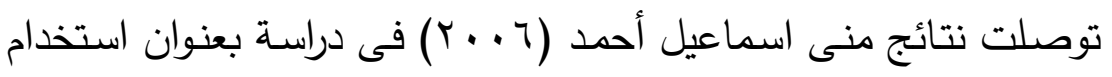
استراتيجية التعلم التعاونى فى تتمية المهارات اللغوية والاجتماعية لطفل الروضـة الى فاعلية المواقف التعليمية المخططة باستخدام نموذج التقصي الجماعي لتنمية مهارة التعبير اللغوي ومهارة الاتصـال الاجتماعي لطفل الروضـة وبالتالي التأكد مـن فاعليـة اسـتخدام اسـتراتيجية الـتعلم التعـاوني في تتميـة المهـارات اللغويـة والمهارات الاجتماعية لطفل الروضة .

\section{المور الثانى: السلوك الاجتهماءى السبلى}

يشـمل السـوك كل مايصسدر عـن الكـائن الحسى مـن أنشطة بسـيطة أو

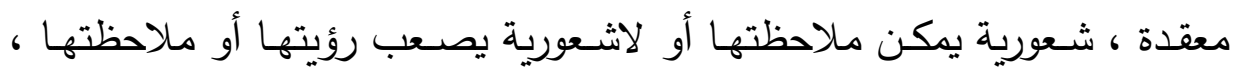

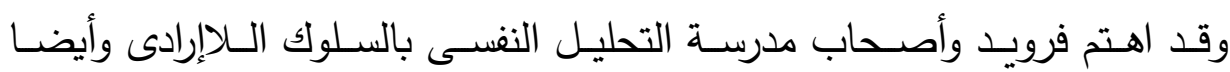
اللاشـورى ، فـى حين اهتمـت المدرسـة السـلوكية بالسـلوك الملاحظظ فى شكله الجزئَى مثثل الفعـل المـنعكس ، بينمـا اهتمـت المدرسـة المجاليـة بدراسـة السـوك كوحدة متكاملة . ( حسين احمد التهامى ، 1 . . r 100: ) . 


\section{المبلة العلمية لكلية رياض الأطفال - جامعة بورسعيد}

\section{العواهل التى تؤثر فى السلوك}

أولاً : الأسرة : فالتنشئة الاجتماعية هى الوظيفة الاجتماعية الرئيسية للأسرة فهى المدرسـة الأولى التى تربى الطفل وتهذب سلوكه وفق المعايير الاجتماعية والمثل العليا، وعلى الوالدين تقع مسؤلية القيام بواجبيهما الاقتصادى والتربوى من خلال الحرص على أن يعيش الطفل حياة هادئة مستقرة .

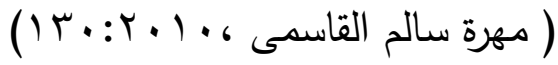

ثانيـًاً : المدربسـة : تعد المدرسـة مؤسسـة اجتماعية متخصصسة يتلقى فيها الطلاب العلم والمعرفة ونقل الثقافة من جيل إلى جيل ، كما أنها تسعى إلى تحقيق هونسيه النمو الجسمى والعقلى والانفعالى والاجتماعى للطفل مما يساعد فى تتشئته التششئة الاجتماعية السليمة ، وتمثل المدرسة المؤسسة التربوية الاجتماعية المقصودة التى تقوم بوظيفة تعليم وتربية الطفل .

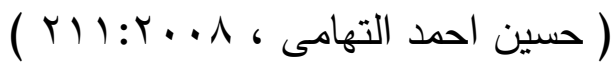

ثالثًا : الثقافة : يتأثر سلوك الفرد خلال عملية التشئُة الاجتماعية بالثقافة العامة للمجتمع الذى يعيش فيه والتى تشمل كل من : المعتقدات والعادات والتقاليد

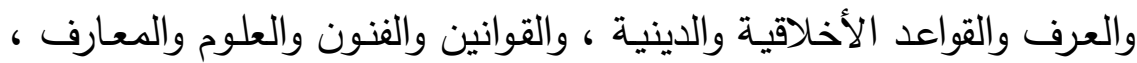

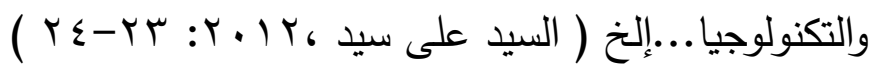

رابعًا : جماعة الآتران : تتألف جماعة الرفاق من مجموعة أفراد يتقاربون فى العمر

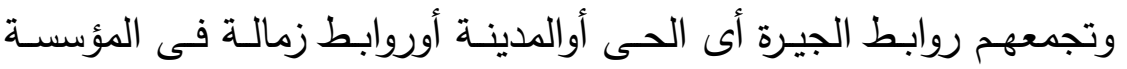

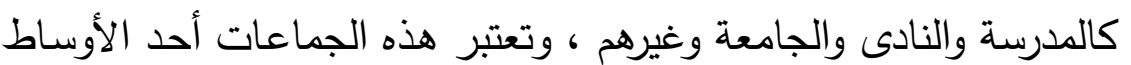

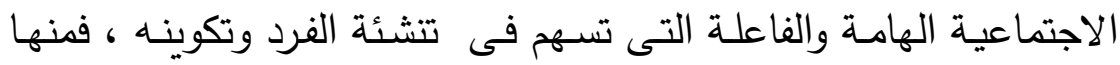
يستمد النشء ثقته بنفسه وبمكانته فمن خلال أقرانه .

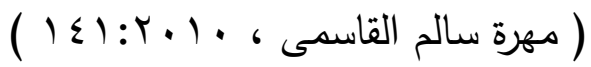

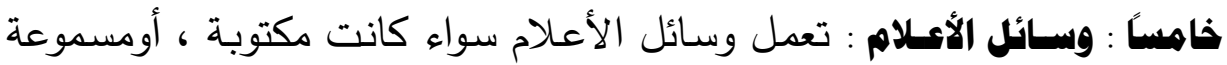

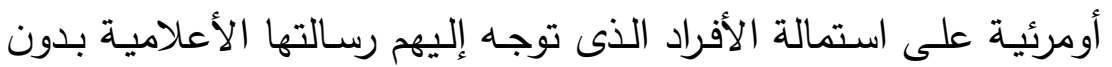

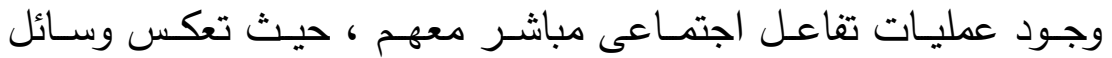

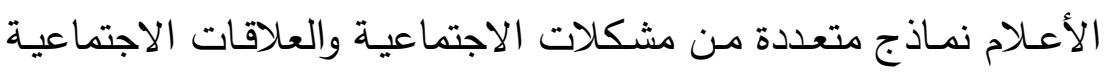




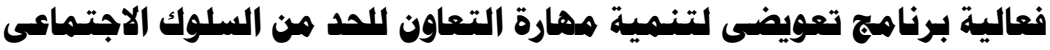 السبى لدى أطفال الروضة قاطنى العشوائيات}

بطـرق جذابـة تشـــ الأنتبـاه ممـا يتـرك تـأثيراً كبيـراً على سـلوك الفـرد

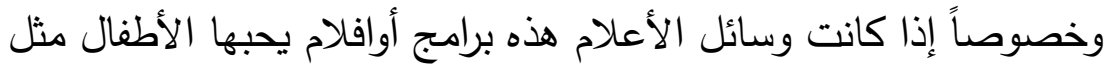

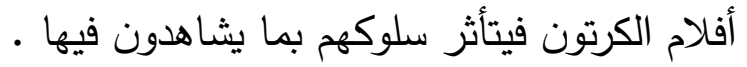

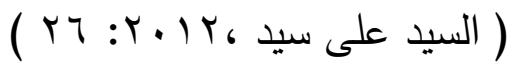

\section{مشاكل السبوك الاجتـماكي :}

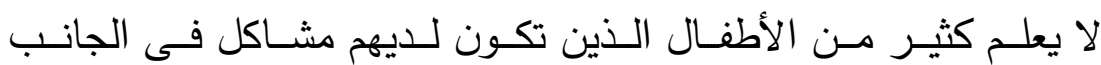

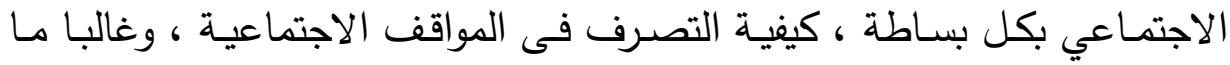

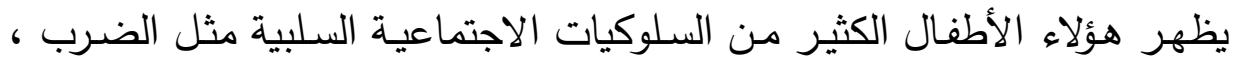

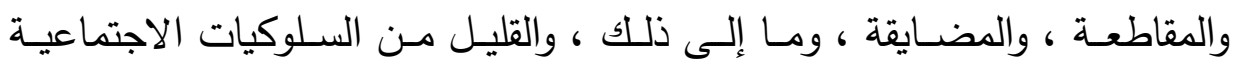

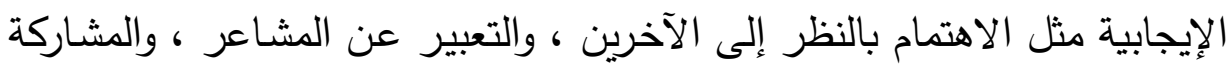

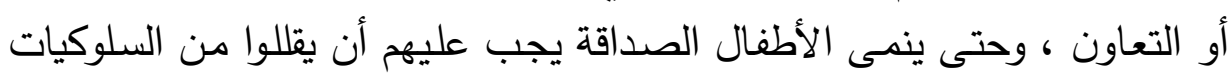

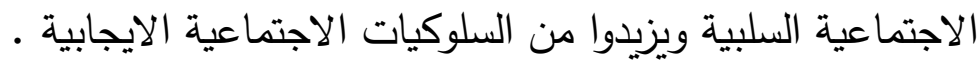

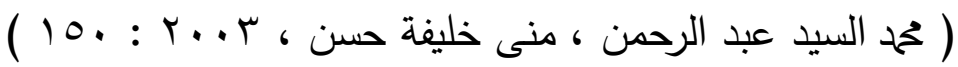

أسلوب تعديل السلوك :

• تقييم المشكلة : أى تحديدها بتغيير بيئة الطفل ، وتبدأ العملية بتحديد المشكلة

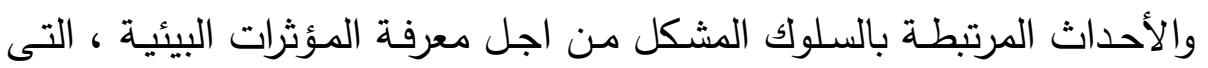

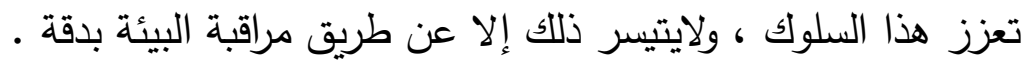

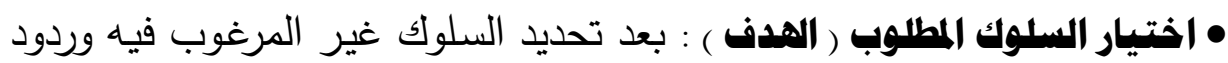

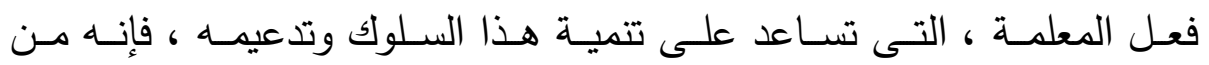

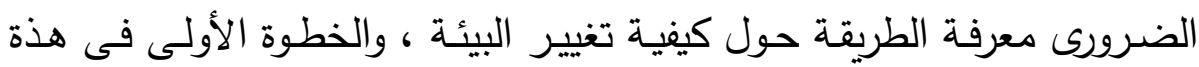

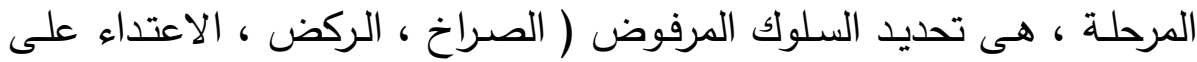

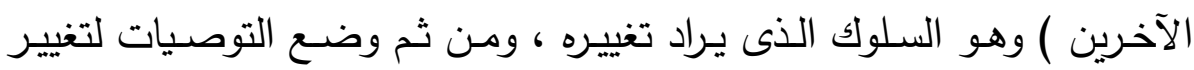

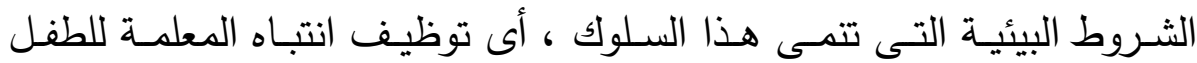

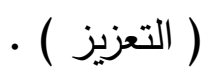

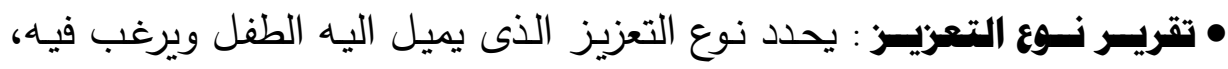

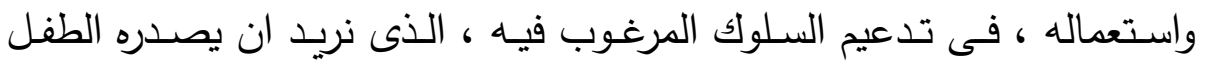
مثل : الجلوس بهدوء ، مشاركته للآخرين .

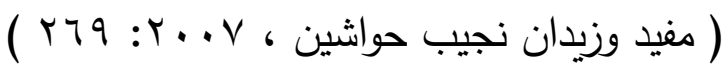




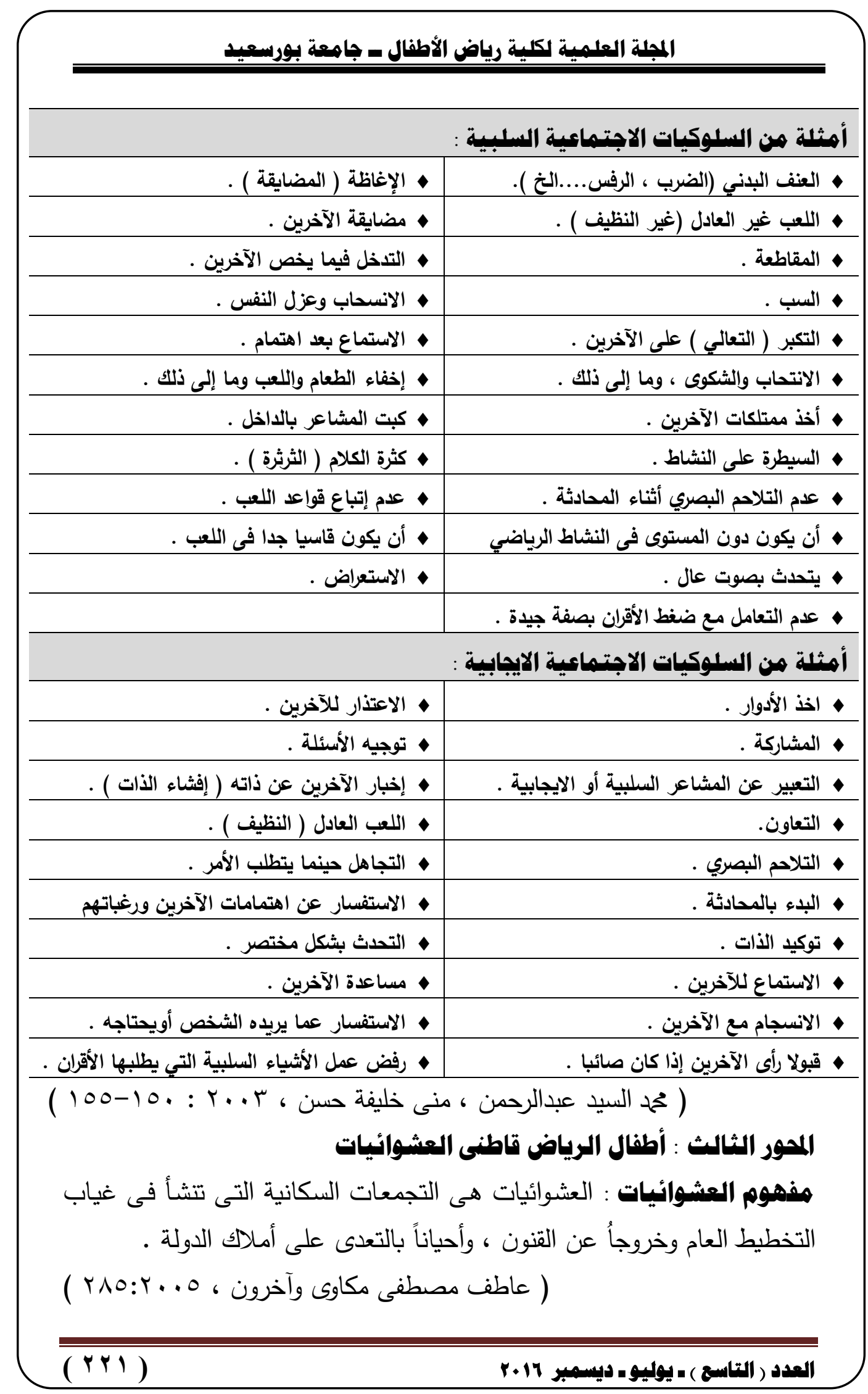


فعالية برناهج تعويضى لتنهية ههارة التعاون للحد من السلوك الاجتهاءى العائ

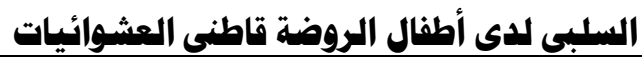

\section{ويعرف أطفال الروضة قاطنى العشوائيات اجرائيًا بأنهم :}

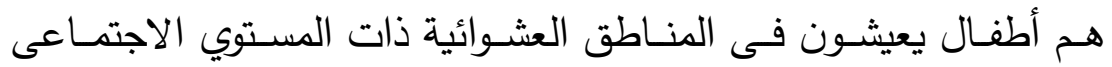

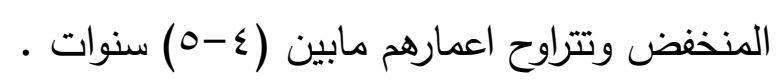

هلاهح البنية الاجتهاعية لقاطني المناطق العشهائية وتأثيرها على الطفل: مائل • العلاقـات الأسسرية : الأسرة هي وحدة المجتمع الأول ، وهي أول خلية يكون

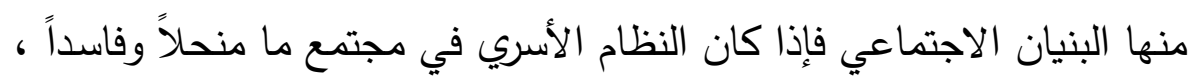
فإن هذا الفساد يتردد صداه في وضعه السياسي وإنتاجه الاقتصادي ومعاييره

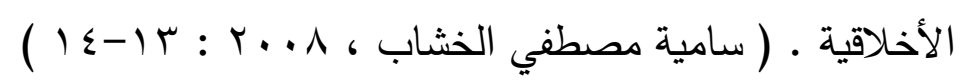

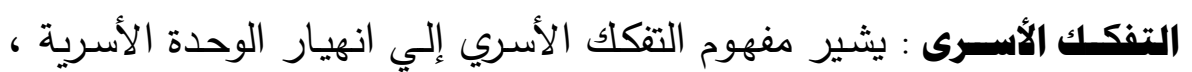

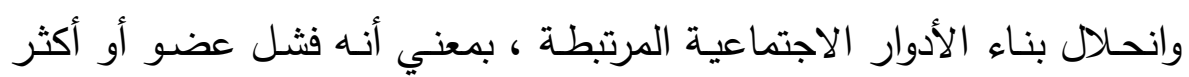

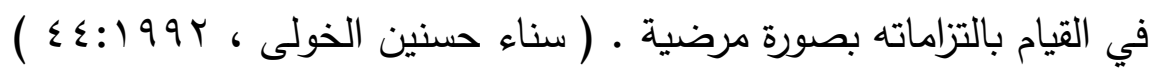
• عدم التنظـيم الاجتهـاعي للأسـرة : لقد تعددت واختلفت المداخل فى رؤيتها للخصـائص الاجتماعيـة لسـاكني الأحياء العشوائية ، فمنهـا مـا يـرى أن هذه المناطق يسودها عدم التنظيم الاجتماعي ، وعدم وجود تماسك اجتماعي أو تعاون بين أفرادهـا ، وهناك مـن يرى أن هذه المناطق تتسم بقدر كبير من التتظيم الاجتماعي الداخلي ، وهناك موقف وسط يؤكد على أن هناك اختلافا بين المناطق العشوائية بعضها البعض ، وأنها جميعاً لا تحمل نفس السمات .

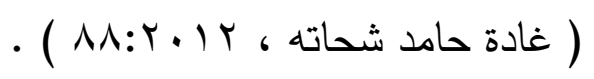
• بر حجم الأسرة : من أهم الخصائص الاجتماعية كبر حجم الأسرة والزحام فى كلى

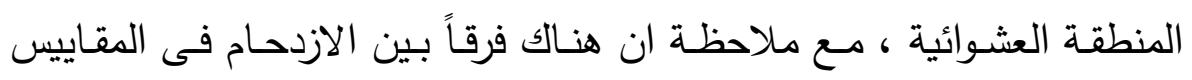

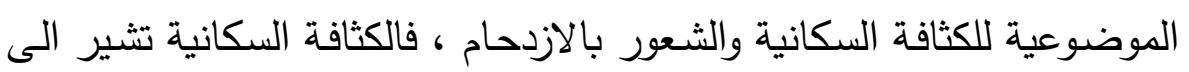
العدد الفعلى للأشخاص الموجودين فى مكان معين ، فهي تقاس بمفهوم عدد

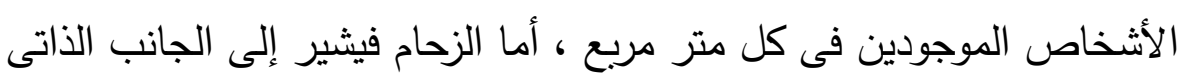
للشعور بالضيق وعدم وجود المكان الكافي • 
• انعدام الخصوصية للأسرة : تعد الخصوصية إحدى المطالب الهامة فى حياة الإنسان ، وهى احتياج طبيعي للإنسان لا يستطيع العيش بدون تحقيق القدر المناسـب منها ، وتعتبر الخصوصية من أهم القيم التى تحافظ على آدمية

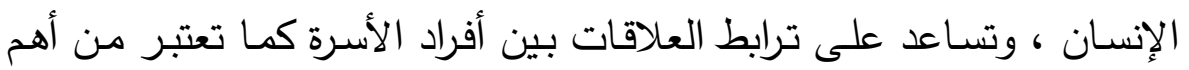

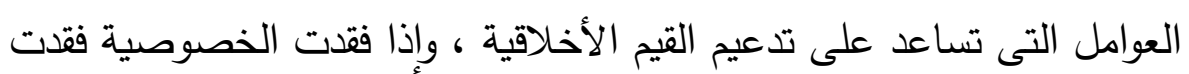

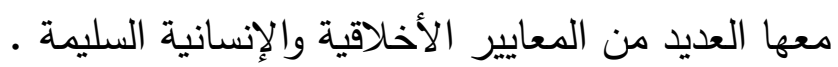

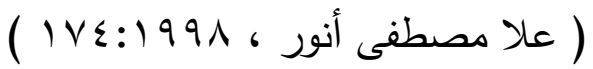
ازدهام الأسـرة : فى المناطق العشوائية التى يتصف المسكن فيها بالازدحام فانه لا يمكن الفصل بين مكان نوم الكبار ومكان نوم الأطفال ، يؤدى ازدحام

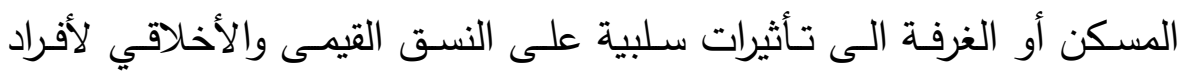
الأسرة بسبب انتفاء الخصوصية وزيادة الإباحية .

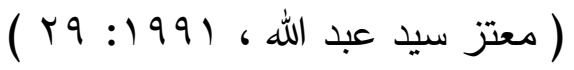
• ضعف الكيان الاجتهاعى للأسرة : يتجسد ذلك فى ضعف انتماء الأفراد لأسرهم

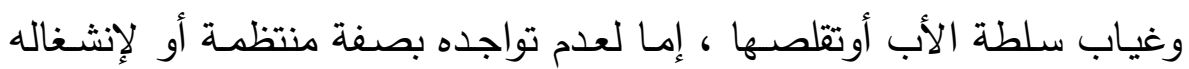

$$
\text { بالسعي وراء الرزق • ( مصطفى محمود مصطفى ، ع ( ـ ب: (9 ) ) }
$$
هذا ماهدفت إليه دراسة نجلاء فرغلي عبد العال (0 . . ب) لتتاولها طبيعة القيم الاجتماعيـة فى المنـاطق العشـوائية بعنوان " القيم الاجتماعيـة لدى سكان

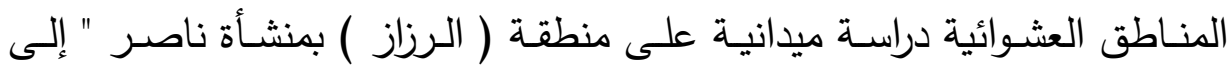
محاولـة الكشـف عـن القيم الاجتماعيـة السـائدة لـدى سـكان المنـاطق العشـوائية.

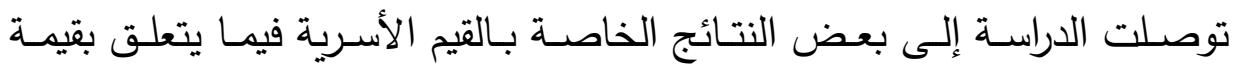

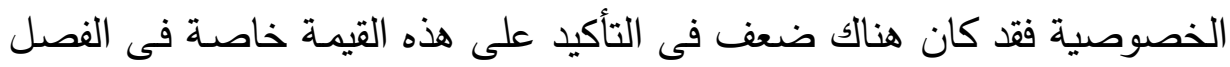
بين الإخـوة من الجنسين ، بالنسبة لقيمـة الجيرة فقد أثرت الحوادث والمشكلات هُهات

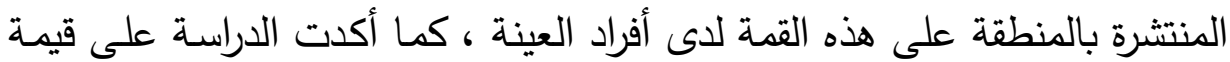
الإنجاب حيث أتت أعلى نسب إنجاب ، أوعدد الأبناء لدى المبحوثين .

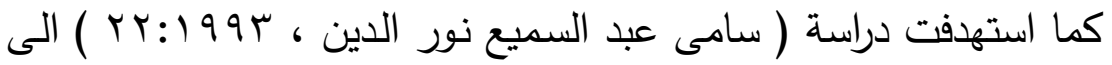
التنشئة فى المناطق الحضرية المحرومة إلى محاولة وصف وتحديد نمط الحياة 


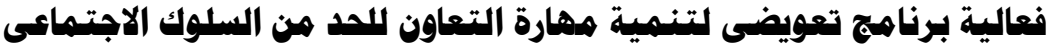 السبى لدى أطفال الروضة قاطنى العشوائيات العيات}

الاجتماعية والثقافيـة ، وذلك كى تستطيع المدرسـة أن تتلائم معسه ، ثم محاولة تحديد مؤسسـات التشـئة والعلاقة بينهما ، وذلك لتكوين أسـاس لتخطيط تربوي سليم بحيث لا يحدث تناقض فى عمل تلك المؤسسـات فى المناطق الحضـرية المحرومة ، وتوصلت الدراسة إلى عدد من النتائج أهمها : أن سكان منطقة منشأة

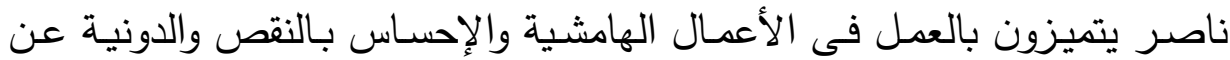
باقي سكان مناطق القاهرة الأخرى نتيجة عمل الأب خارج المنزل طوال اليوم فى الإلى

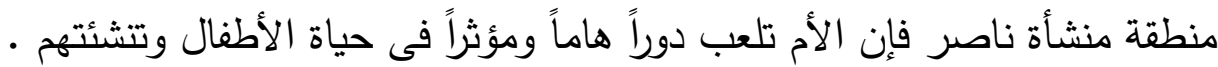

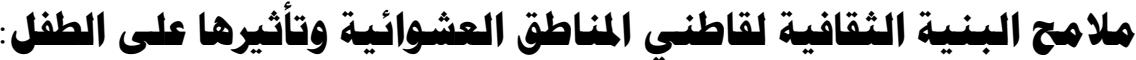

ممـا لاشـك فيـه أن ملامـح البنيـة الثقافيـة للمنـاطق العشـوائية لا تنفصل بحال من الأحوال عن ملامح البنية الاجتماعية ، حيث تؤثر الملامح الاجتماعية

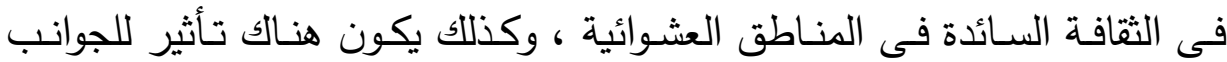
الثقافية على أشكال التفاعل الاجتماعى بتلك المناطق ، ونجد أن الملامح الثقافية

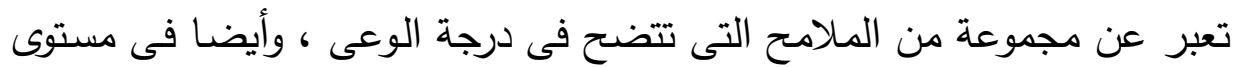
التعليم ، وتوافر المدارس والمؤسسات الثقافية ، ونسب الأمية بتلك المناطق ، كما تتضح فى مدى الوعى الصحى ، وتواجد المستشفيات ، كما تعد ثقافة الزحام من

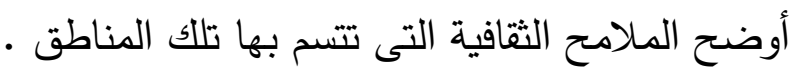

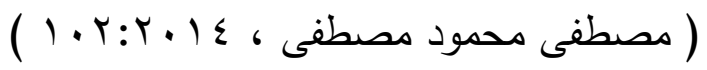

أمـا عـن الأوضـاع الثقافيـة فـى المنـاطق العشـوائية قـدمت مـريم أحمـد مصطفى (99V ( ) دراسة عن الخصائص الاجتماعية والثقافية للمناطق العشوائية وقد توصلت إلى العديد من النتائج ، منها أن أهم المشكلات الاجتماعية والثقافية هـى مشكلة التزاحم وارتفـاع الكثافـة داخل المسكن ، والذي يؤثر على التشـئة

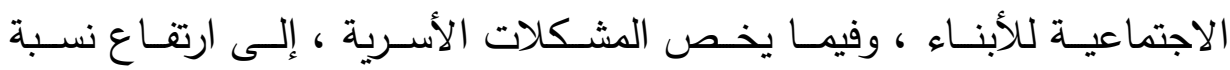

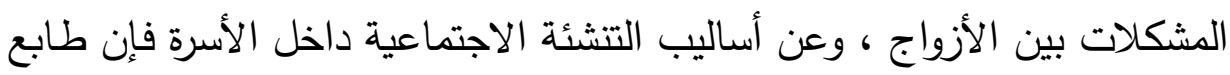
العنف والقسوة كان هو المسيطر على عملية التنشئة إلى حد كبير .

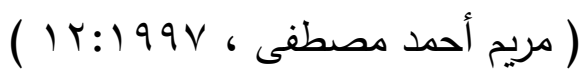




\section{المبلة العلمية لكلية رياض الأطفال = جاهعة بوريعيد}

\section{انعكاسات هشكلات السكن العشوائى على أطفال الروضة:}

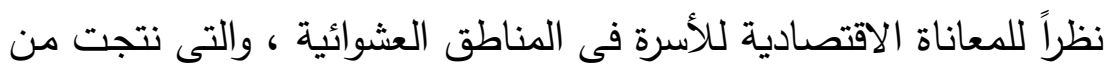

انخفاض مستوى الاخل ، الذى يصل الى حد الفقر وما تحته ، مع زيادة فى عدد أفرادها ، وتكدسهم فى مأوى تتسم بالضيق ، فإن هذه الأسر تلجأ إلى استخدام

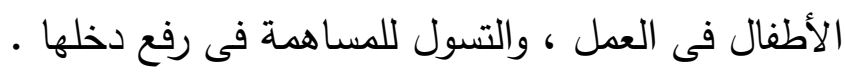
( عزة كريم ، (109199 )

وإذا كـان عمـل الأطفـال يحفـل بأوضـاع غيـر ملائكـة بالنسـبة للمرحلـة

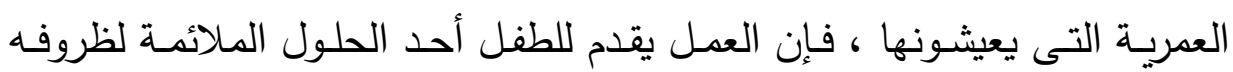

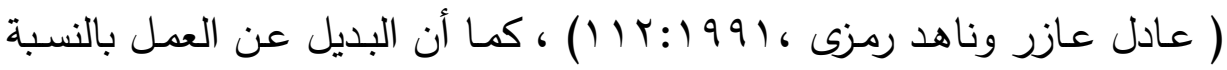
لبعض هؤلاء الأطفال الذين لم يلتحقوا بالتعليم ، أو تسربوا منه فى مرحلة مبكرة ،

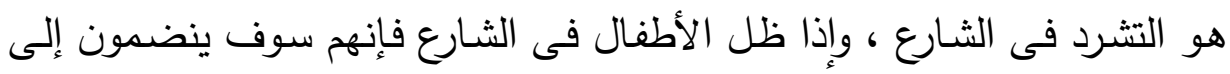
الفئة التى بدأت تشكل ظاهرة حاليا ، وهى فئة أطفال الشوارع ، لذلك يعتبر العمل

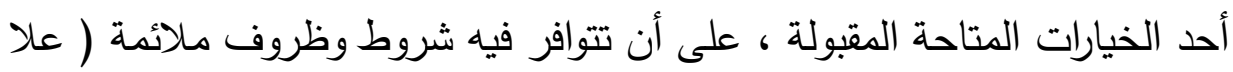

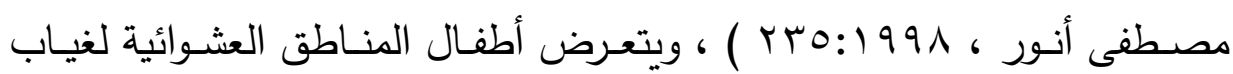
الرقابة والاهتمام ، كما يتعرضون لسوء المعاملة ، ويعانون من سوء التغذية . (Weaver-Zercher, Valerie, 2008: 43-44)

\section{هما سبق نبد أن الطفل يواجه العديد هن المشاكل داخل هذه المناطق هنها:}

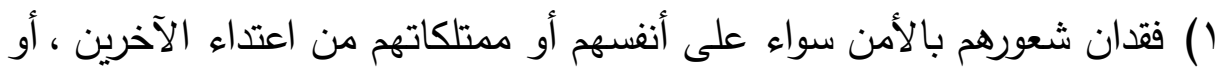
الأمن على منازلهم وعششهم من قرار الإزالة ، واحتمالات تشردهم فى الشارع.

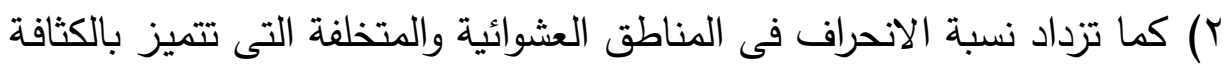

$$
\text { العالية فى عدد السكان ، وتقل فيها أماكن الترويح والترفيه . }
$$

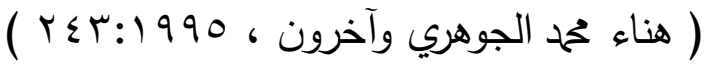

كل هذا يترك آثاره السيئة فى حياة الطفل فلا شك أن هذا الجو الفاسد لا

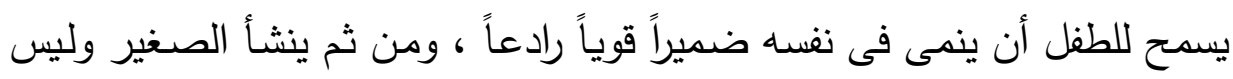

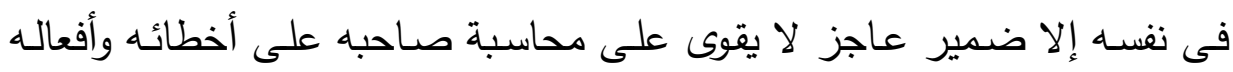




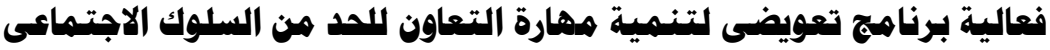 السبى لدى أطفال الروضة قاطنى العشوائيات}

التى تتعـارض مـع قيم الدين والمجتمـع ، بالإضـافة إلى العدوان والعنف الذَى

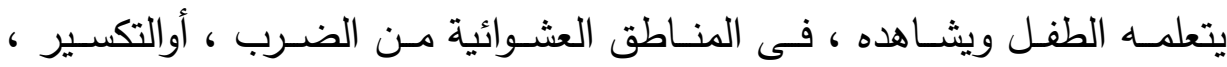

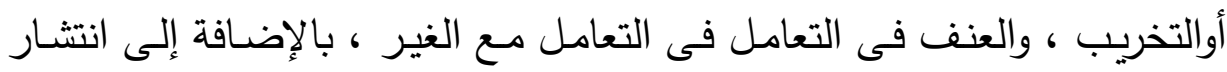

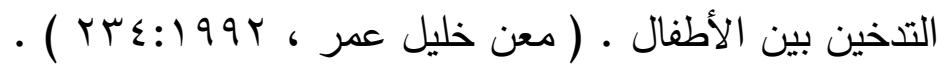

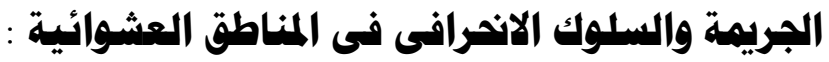

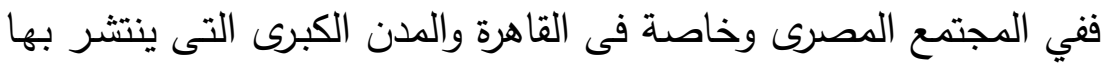

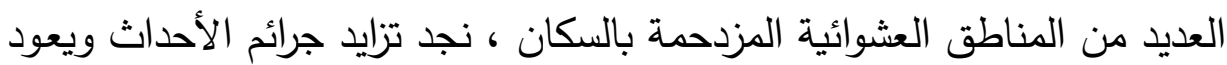

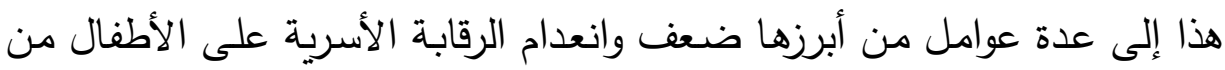
ناحية ، والتفكلك الأسرى نتيجة انتشار حالات الطلاق والانفصال من ناحية ثانية، فتأثير الوسط الاجتماعي والتنشئة على الطفل عظيم الأثر .

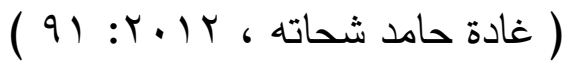

وتجد الفئات الخارجة عن القانون المناطق العشوائية أنسب المناطق مأوى عاده الته لهم حيث تتسم هذه المناطق بعدة سمات تجعل أيدى الشرطة لا تصل إليهم ،

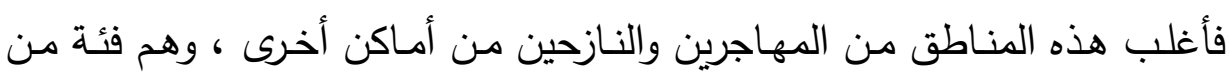
الفقراء المعدمين • (Taylor,Erin B,2009:157) وأما عن نوعية المشكلات الخاصة بالجريمة والسلوك الإنمرافى أوالسلوك

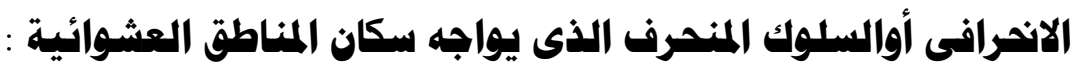

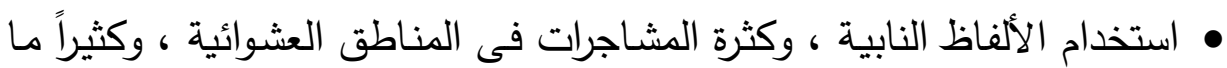

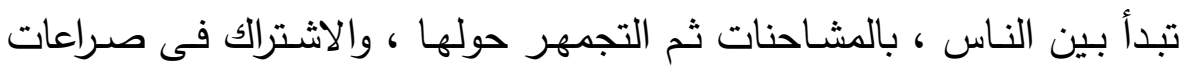

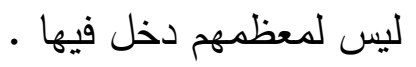

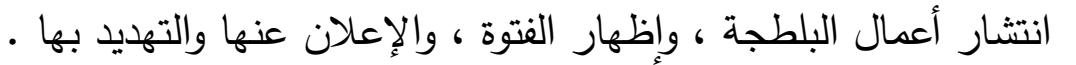

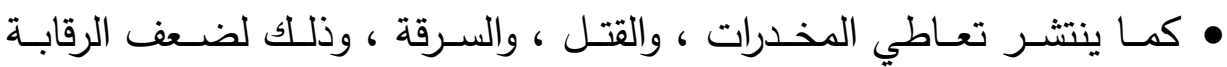
الحكومية على هذه المناطق ، فقد أصبحت مراكز لتوطين المجرمين . • الاغتصاب مشكلة أخرى تنشأ بكثرة بين سكان هذه المناطق العشوائية نتيجة

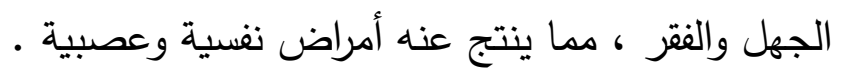

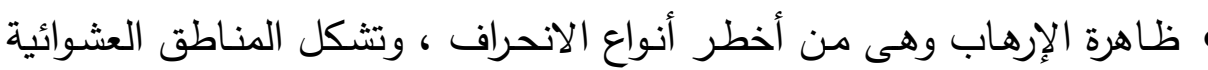

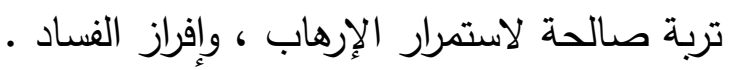




\section{الإجراءات المنهمية للدراسة :}

هـذهج الدراسسة : استخدمت الدراسة الحالية المنهج شبه التجريبي ذو المجموعة

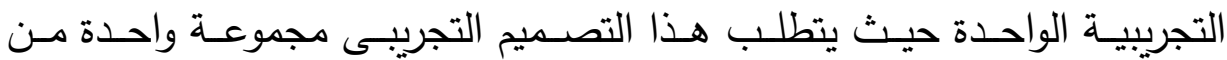
المفحوصين ( الربيع الأعلى ) الأطفال الأكثر سلبية حتى يمكن ملاحظة سلوكهم

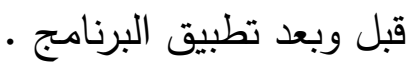

هجتهع الدراسسة : ويتمثل مجتمع الدراسـة في روضـة المسجد الأقصى الابتدائية الموجودة بالقرب من المنطقة العشوائية عزبـة أبو عوف التابعة لإشـراف التربية

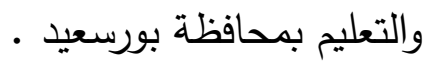

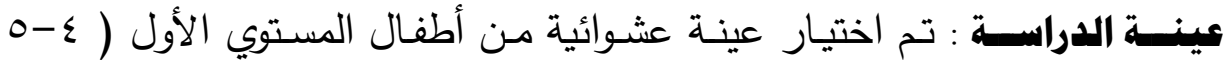
سنوات ) داخل الروضة وبلغ قوام العينة ( 10 طفل وطفلة ) . فروض الدراسة :

() توجد فروق ذات دلالة إحصائية بين متوسطي رتب درجات أطفال الروضـة قاطنى العشوائيات بين التطبيق القبلى والبعدى على مقياس مهارة التعاون لصالح التطبيق البعدى . لإل r) لا توجد فروق ذات دلالــة احصـائية بين متوسطات رتب درجـات الأطفـال

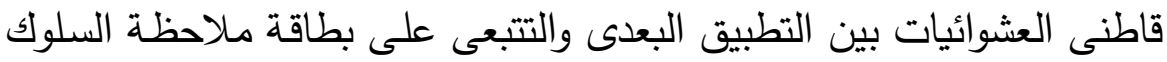

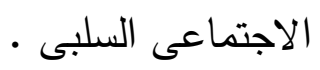

\section{أدوات الدراسة :}

بطاقة ملاحظة السلوك الاجتهماكى السلبى : ( إعداد الدارسة) وقد مرت عملية إعداد بطاقة الملاحظة بالخطوات التالية :

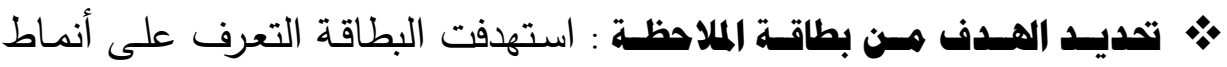

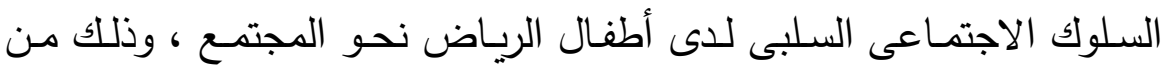
خلال ملاحظة سلوك الأطفال في الجوانب المختلفة .

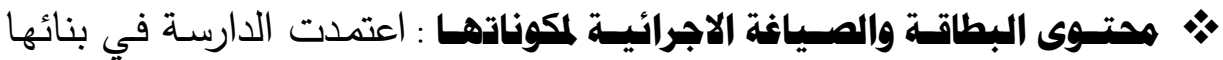
لبطاقـة الملاحظـة على مصـدرين اساسـيين همـا : ( الأدبيـات ، والدراسـات والبحوث السـابقة التي تتاولت أطفال الرياض ممن لديهم سلوك سلبى غير

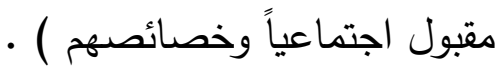




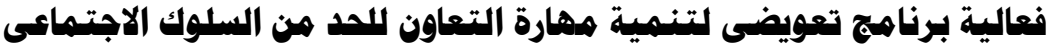 السبى لدى أطفال الروضة قاطنى العشوائيات}

وفي ضوء هذين المصدرين قامت الدارسة بتحليل كل جانب دن جوانب

الملاحظة إلى مجموعة من السلوكيات ، وقد راعت الدارسة عند صياغتها أن : تتضمن كل عبارة سلوكاً واحداً فقط يقوم به الطفل . تصاغ في جمل بسيطة يسهل على المعلمة فهمها . تستخدم عبارات قصيرة . • مديد أسلوب الملاحظـة : استخدمت الدارسة أسلوب ملاحظة السلوك الفعلي

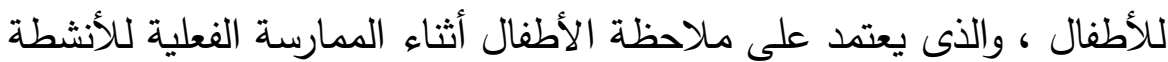
التعليمية المختلفة . صـياغة تعليهـات بطاقسة الملاحظــة : قامت الدارسـة بوضـع مجموعـة من التوجيهات في الصفحة الأولى تتضـن كتابـة البيانات الخاصـة بكل طفل ( الاسم - السن - النوع - المستوى التعليمي ) ، وهناك في الصفحة الثانية مجموعـة مـن التعليمـات الخاصـة بالمعلمـة توضـح : ( الهدف مـن بطاقـة الملاحظة كأداة لتحديد الأطفال الذين لديهم سلوك غير مقبول اجتماعياً ، الإجراءات التي تتبعها المعلمة عند ملاحظة سلوك الأطفال ) . تهديد أسلوب تسبيل الملاحظة : يتم تحديد السلوكيات التي يقوم بها الطفل

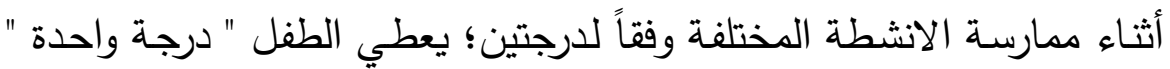
إذا تكرر حدوث الصفة أوالسلوك بحد أدني ثلاث مرات خلال خمسة أيام في الاسبوع ، يعطي الطفل "صفر " إذا لم يتكرر حدوث الصفة ، ولم يظهر فيه

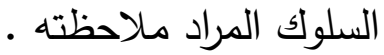

وتقوم المعلمة بوضـع علامـة ( ل ) أمـام الصفة أوالسلوك الذي يظهر للى مأى الطفل وذللك علي مدار ( 0 ) أيام في الاسبوع، وذلك للتأكد أن هذه الصفة سـائدة عنده وليست مجرد سلوك عارض وبتجميع هذه الدرجات في ضـوء العلامـات الموضوعة يمكن تحديد الدرجة الكلية للبطاقة الخاصـة بكل طفل هـاه والتي يمكن في ضوئها التعرف على الأطفال ذوى السلوكيات غير المقبولة

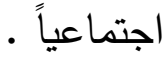


صـدق بطاقسة الملاحظـة : بعد إعداد الصورة الأولية لبطاقة الملاحظة ، قامت الارســة بعرضـها على مجموعـة مـن السـادة المحكمـين مـن أعضــاء هيئسة التدريس في رياض الأطفال والمناهج وطرق التدريس وعلم النفس وذلك للتأكد

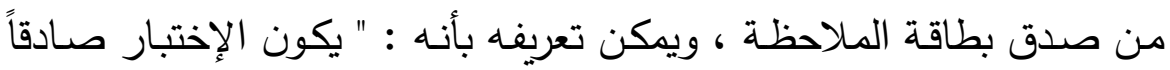

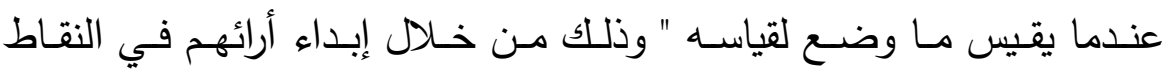
التالية : ( ) دقة وصحة تعليمات البطاقة .

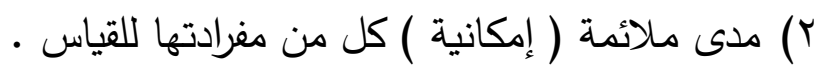

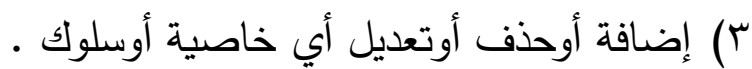

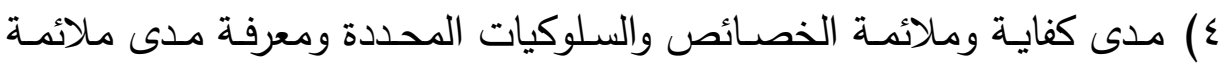
البطاقة لتحقيق الهدف منه .

\section{وقد تمثلت ملاحظات السادة المكمين فيهما يلي :} ( الموافقة على دقة وصحة تعليمات البطاقة .

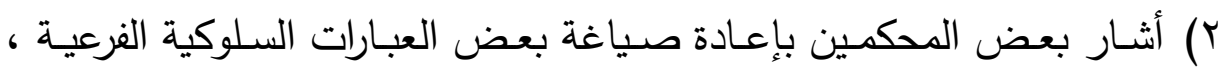
حيث يمكن ملاحظتها وقياسها ، وقد قامت الدارسة بعمل التعديلات اللازمة .

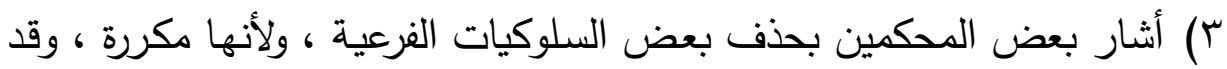

$$
\text { تم عمل التعديلات اللازمة . }
$$

ع) الموافقة على ملائمة البطاقة لتحقيق الهدف منها ، ومن هنا يمكن القول بأن

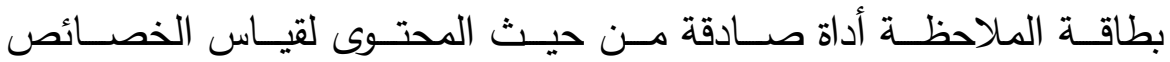

$$
\text { والسلوكيات التي تضمنتها البطاقة . }
$$

تم استبعاد (V)عبارات لم تحصل علي نسبه الاتفاق 80\% بين المحكمين • تم حسـاب النسبة المئويـة لإتفاق المحكمين على المفردات وبنـاء على آراء المحكمين تم حذف المفردات التى لم تحصل على نسبة 80\% فأكثر وتم تغيير بعض الصياغات لزيادة وضوحها .

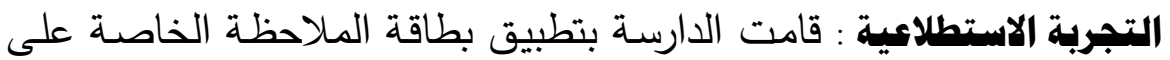
عينة استطلاعية قوامها (OV) طفلاً وطفلة بروضة المسجد الأقصى بالمنطقة لإنة 
فعالية برناهم تعويضى لتنهية ههارة التعاون اللد هن السلوك الاجتهاءى

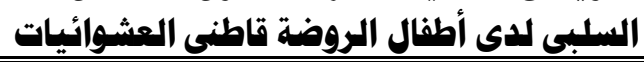

العشوائية بمحافظة بورسعيد وذلك بهدف حساب كلا من : معامل الثبات ، وزمن تطبيق بطاقة الملاحظة .

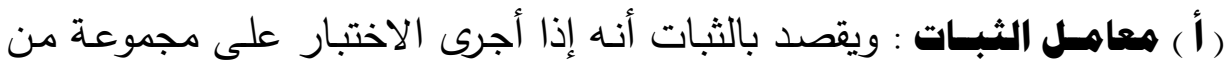

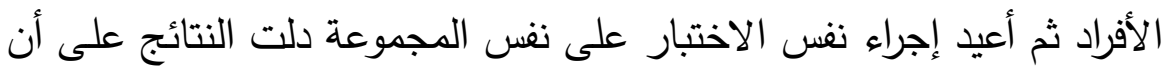
الدرجات التى حصل عليها الطلبة فى المرة الأولى والثانية هى نفس الدرجات يستتتج من ذلك أن نتائج الاختبار ثابتة تماماً ، لأن نتائج القياس لم تتغير فى المرة الثانية بل ظلت كما كانت قائمة فى المرة الأولى .

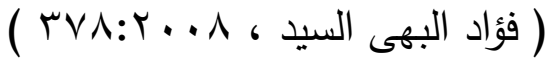

ثبات بطاقة الملاحظـة : ويعرف ثبات بطاقة الملاحظة بأنهـ " دقة البطاقة في الملاحظة وعدم تتاقضـها مع نفسها ، واتساقها فيما تزودنا به من معلومـات عن سلوك المفحوص " ( فؤاد أبو حطب وآخرون ، 1 . . ب: 1 • 1 ) . لحسـاب معامل الثبات استخدمت الدارسـة: طريقة بيرسون وكان معامل

$$
\text { الثبات 99\% عند مستوي ا ـ.,.• }
$$

( ب ) زمن تطبيق بطاقة الملاحظة : لتحديد الأطفال ذوى أنهاط السلوك الاجتهـاءى السـلبى : بحسـاب متوسط الذى استغرقته معلمات الروضـات اللاتي قمن بتطبيق استمارة الملاحظة ، تم تطبيق استمارة الملاحظة خلال أسبوعيين

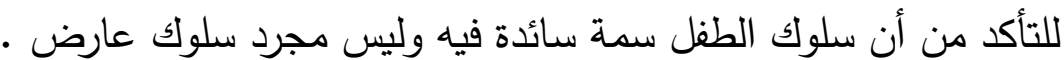
الصورة الذهائية لبطاقة الملاحظة : بعد ضبط بطاقة الملاحظة وحساب كل من الصدق والثبات ، وضعت الاستمارة في صورتها النهائية ، وقد بلغ عدد مفرداتها (00) مفردة وبذللك أصبحت الاستمارة جاهزة للتطبيق . إجـراء عمليسة الملاحظسة : تم تطبيق بطاقة الملاحظـة علي أطفـال المستوي

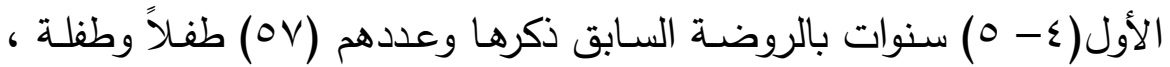

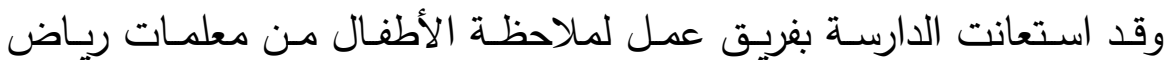

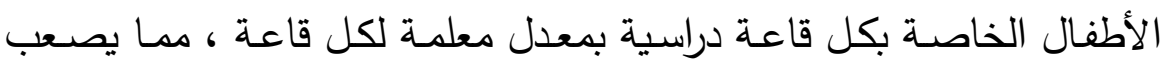
عليها أن تقوم بهذه الملاحظة نظراً لأنها تحتاج إلي تواجدها مـع الأطفال يومياً أثنـاء دراستهم للأنشـة المختلفـة للحكم عليهـا علي مدار أسـبوعين 
متواصـلين وقد قامـت الدارسـة بتوجيـه فريـق الملاحظـة نحـو كيفيـة تطبيق

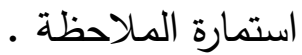

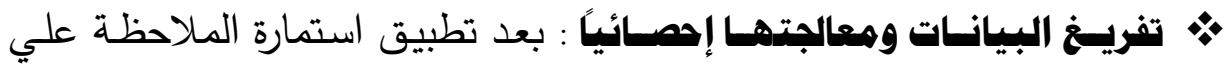

العينـة من أطفال المستوي الأول من سن (ع-0) أثناء ممارستهم لأنشطتهم

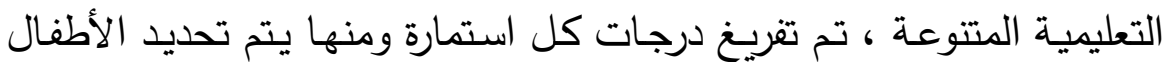
الذين حصلوا علي (\% \% مأكثر من الدرجة النهائية لاستمارة الملاحظة ويتم

$$
\text { تفريغها في جداول خاصة . }
$$

حجم عينة البحث : اسفرت النتائج الإحصائية عن وجود عينة من الأطفال ذوى السلوك غير المقبول اجتماعياً وبلغ عدها(0 1) طفلاً وطفلة بالمستوى الأول .

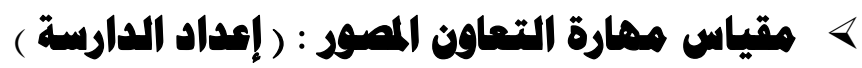
وقد مرت عملية بناء المقياس بالخطوات التالية : () (مديسـ الهـدف هـن المقيساس : يهدف المقياس إلى تقدير مدى آداء الطفل

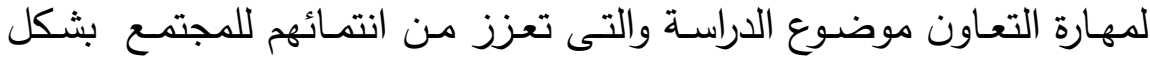
يرقى الى حد كبير بسلوكه ، فمن خلالها يستطيع الطفل أن يتفاعل مـع الآخرين ، ويندمج معهم ، ويشاركهم ألعابهم ويتعاون معهم في انجازها .

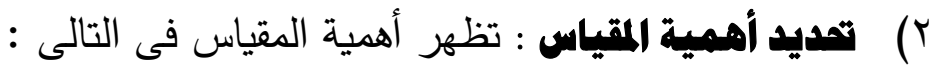
• عـد آداه للمعلمـين والمتخصصـين والقـائمين على تربيـة طفـل مـا قبـل المدرسة للكشف عن مدى إكتساب الطفل لبعض المهارات الاجتماعية . قد تقيد معدى برامج الأطفال لتعديل البرامج الحالية من خلال محتوى هذا المقياس الذى تم صياغته فى إطار خصائص وإحتياجات نمو الطفل . r) وصف المقياس : يتتاول هذا المقياس بعض المهارات الاجتماعية كما حددتها الدارسة حيث يتكون من (•r) عبارة موزعة على ست أبعاد تصف كل منها آداء الطفل فى بعض المواقف التى يمر بها فى الروضة .

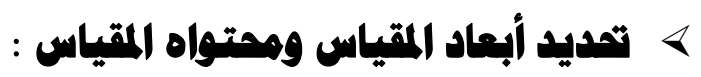

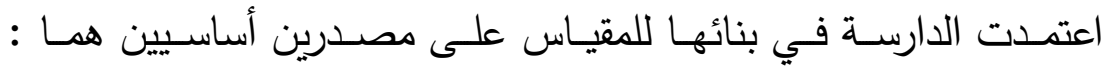
( الأدبيات ، والدراسات والبحوث السابقة التي تتاولت مهارة التعاون ) . 
وفي ضـوء هذين المصدرين قامت الدارسـة بتحليل كل بعد مـن أبعـاد

المقياس إلى مجموعة من السلوكيات، وقد راعت الدارسة عند صياغتها أن:

- يتضمن كل سؤال سلوكاً واحداً فقط يقوم به الطفل.

- تصاغ الاسئلة في جمل بسيطة يسهل على المعلمة فهرها.

- ت تكون الاسئلة قصيرة وواضحة.

- - تكون الصورة معبرة عن كل مفردة ومبسطة لتتناسب مع طفل الروضة.

\section{> مياغة تمليسمات الاقياس :}

قامت الدارسة بوضع مجموعة من التوجيهات في الصفحة الأولى تتضمن

كتابة البيانات الخاصـة بكل طفل( اسم الطفل - السن - اسم الروضـة - تاريخ التطبيق ) ، وهنالك مجموعة من التعليمات التى توضتح تعليمات المقياس وكيفية

تطبيقه .

\section{> تمديد نوع الاقياس وطريقة تصميحه:}

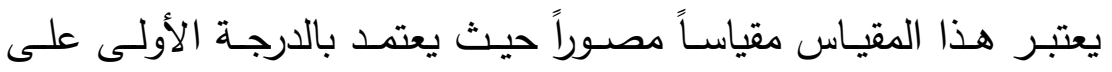

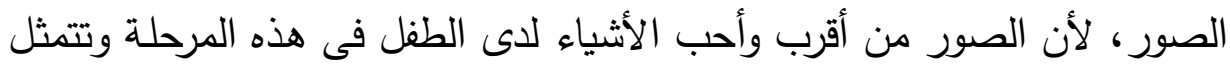

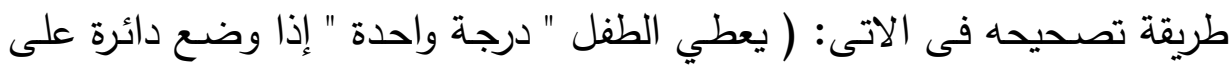

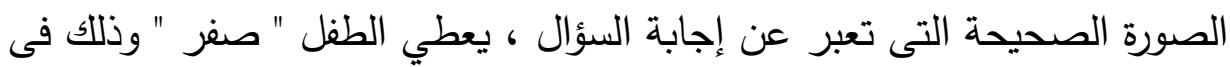
الحالتين التاليتين :

- إذا وضع دائرة على صورة غير صحيحة لا تعبر عن إجابة السؤال .

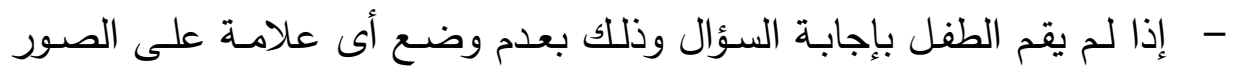

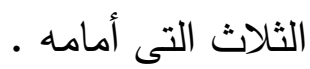

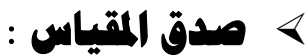

بعد إعداد الصورة الأولية للمقياس، قامت الدارسة بعرضسه على مجموعة

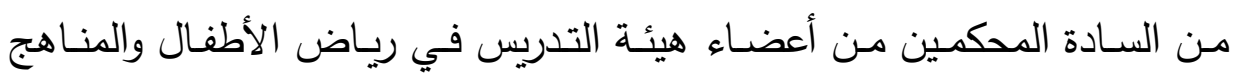

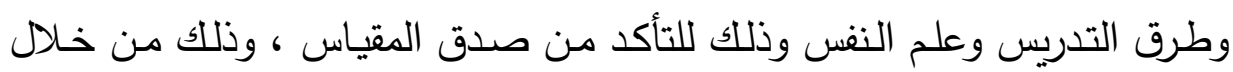

إبداء آرائهم في النقاط التالية :

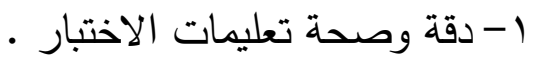




\section{المجلة العلمية لكلية رياض الأطفال ــ جاهعة بورسعيد}

r- مدى ملائمة ( إمكانية ) كل من مفرادت المقياس للقياس •

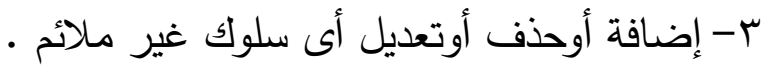
ع- مدى كفاية وملائمة المفاهيم والسلوكيات المحددة ومعرفة مدى ملائمة المقياس لتحقيق الهدف منها .

\section{وقد تمثلت ملاحظات السادة المكمين فيما يلي :} 1- الموافقة على دقة وصحة تعليمات المقياس. r- أشار بعض المحكمين بإعادة صياغة بعض الاسئلة ، حتى يمكن ملاحظتها وقياسها ، وقد قامت الدارسة بعمل التعديلات اللازمة . أثـار بعـض المحكمـين بتغييـر بعض الصـور لعـدم وضـوحها ، وقـد تـم عمـل التعـديلات اللازمــة ، تـم اسـتبعاد (· ( ) عبـارات لـم تحصـل علـي نسبه الاتفاق 80\% بين المحكمين • تـم حسـاب النسـبة المئويـة لإتفـاق المحكمـين على المفـردات وبنــاء على آلى آراء المحكمـين تـم حـف المفـردات التـى لـم تحصـل على نسـبة 80\% فأكثر وتم تغيير بعض الصياغات لزيادة وضوحها . ب- الموافقة على ملائمة المقياس لتحقيق الهدف منه . ع- إعداد المقياس فى صورته النهائية للتطبيق • ومن هنا يمكن القول بأن المقياس أداة صادقة من حيث المحتوى لقياس الخصائص والسلوكيات التي تضمنها المقياس ، حيث اعتمدت الدارسـة لحساب صدق البطاقة ومناسبتها لما تقيسه على صدق المحكمين •

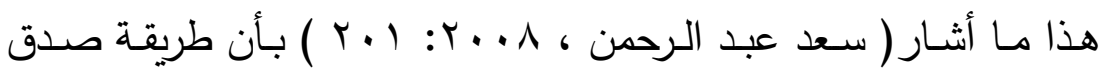
المحكمين أو( طريقة استطلاع آراء المحكمين ) تعتبر من طرق تعيين معامل صدق الاختبار أوالمقياس حيث تعتمد هذه الطريقة على فكرة صدق المحتوى أوالصدق المنطقى ويحسب هذا الصدق على فحص مستوى مدى تمثيلها للسلوك الذى يقيسـ الاختبار وكذلك للتأكد من أن الأسئلة تغطى جميع جوانب السلوك 
فعالية برناهج تعويضى لتنهية ههارة التعاون للحد من السلوك الاجتهاءى العائ

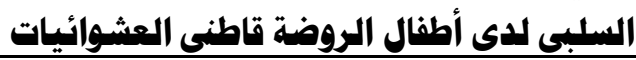

( خير الدين على عويس ، 999 1: ror ) بمعنى أن يقدر المتخصص مدى علاقة كل بند من بنود الاختبار أوالمقياس بالسمة أوالقدرة المطلوب قياسها ، وذللك بعد توضيح السمة أوالقدرة بصورة إجرائية . التجربسة الاسـتطلاعية : قامت الدارسـة بتطبيق الاختبار على عينة استطلاعية قوامها ( OV ) طفلاً وطفلة بروضة المسجد الأقصى بالمنطقة العشوائية بمحافظة بورسعيد وذللك بهدف حساب ثبات الاختبار : لهساب هعاهل الثبات استفدهت الدارسة: طريقة بيرسون وكان هعاهـل الثبـات

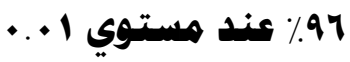
وقد وجد أن معامل ثبات ألفا باستخدام الفا كرونباخ = ( ب^\% ) وهي قيمة مناسبة تؤكد اتساق استمارة الملاحظة . ه الصسورة النهائيسة للمقيساس : بعد ضبط المقياس وحساب كل من الصدق والثبات ، وضـع المقياس في صورته النهائية ، وقد بلـغ عدد مفرداته ( · م) مفردة موزعة على (T) أبعاد مختلفة .

\section{البرناههج التعويضى: ( إعداد الدارسة )}

\section{إجراءات تطبيق البرناهم التهويضى :}

قامت الباحثة باختيار عينة الدراسـة والتي تتوافر فيها الثـروط السـابقة

وطبق عليهم بطاقة ملاحظـة السـلوك الاجتمـاعى السـلبى ( اعداد الباحثة ) ، ومقياس مهارة التعاون المصور ( إعداد الباحثة ) بعدها تم عرض البرنامج على العينة وبعد انتهاء البرنامج تم القياس البعدى لبطاقة الملاحظة والمقياس المصور المستخدمين لمعالجة نتائج التطبيق البعدى بالأساليب الإحصائية الملائمة . أساليب بناء البرنامهج: راعت الباحثة كافة الثروط لبناء البرامج النفسية الخاصة بطفل الروضة. 
البزناهم التهويضى:

أهمئة البرنامهج التهمويضى:

تتضح أهـية البرناهم التعويضي فيسها يلي :

( ) الإهتمام بمرحلة هامة من مراحل نمو طفل ما قبل المدرسة .

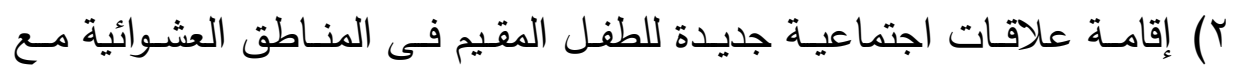

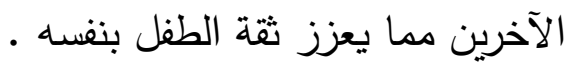

r) يساعد البرنامج التعويضي الطفل في المرحلة العمريـة ( ع-ه سنوات ) على تكوين عـادات وأنمـاط سلوك إيجابية وفعالة نحو المجتمع التى يعيش فيها

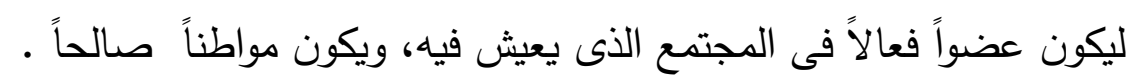

\section{الهدف العام هن البرناهمج :}

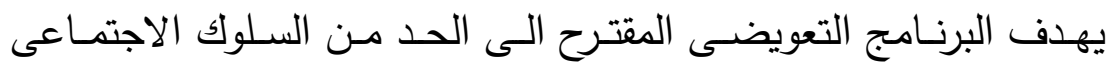
السلبى لدى أطفال الروضـة قاطنى العشوائيات من (ع - -ه سنوات) وتحقيقاً لهذا الهدف فسوف يتتاول البرنامج التعويضى تتمية الأبعاد التالية : ههارة العمل البماعى والتعاون همع الزمهلاء وتشسمل:

$$
\begin{aligned}
& \text { • القدرة على التواصل مع الآخرين. } \\
& \text { • • • •قديم المساعدة الآخرين } \\
& \text { • المشاركة النشطة والفعالة مع الاخرين • }
\end{aligned}
$$

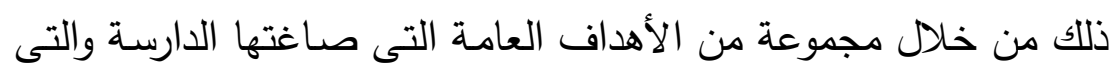
يتوقع أن يكون كل طفل من أطفال المجموعة قادراً على تحقيقها بعد الانتهاء من

$$
\text { البرنامج التعويضى وهى : }
$$

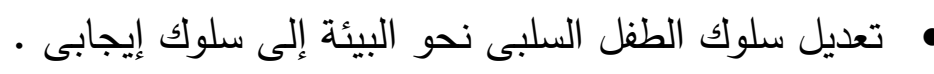

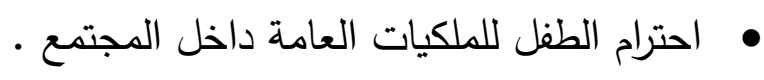

• حث الطفل على النظام و الالتزام به سواء فى( المنزل - الروضة - الثارع )

• حث الطفل على النظافة ( الشخصية - البيئية ) .

• حث الطفل على الاهتمام بالبيئة وكيفية تجميل البيئة . 


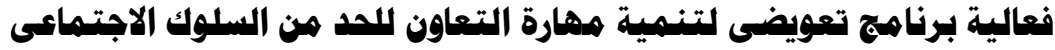

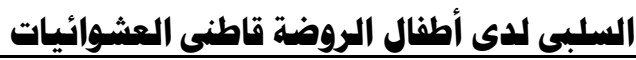

استخدام أسلوب التدعيم ( التعزيز الايجـابى ) المـادى أوالمعنوى فى تعديل

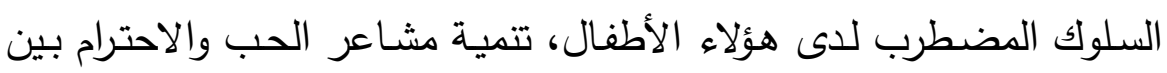

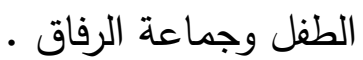

حث الطفل على إقامة علاقات اجتماعية جيدة مع الآخرين. حث الطفل على مشاركة زملاءه في الأنشطة والبعد عن الوحدة والعزلة. تتمية اتجاهات الطفال الايجابية نحو المشاركة والتعاون .

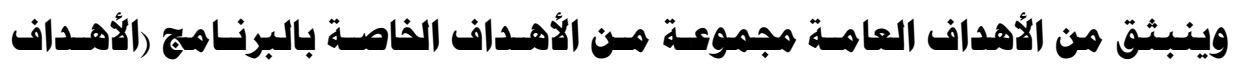
الإجرائية للبرناهمج):

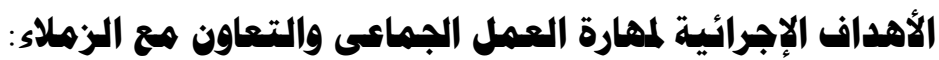

• أن يشارك الطفل زملائه والدارسة فى إعداد سلطة الفواكه بروح التعاون. • أن يصنع الطفل سلطة الفواكه بمعاونة معلمته بمهارة. • أن يغسل الطفل الفواكه مع أصدقائه بإتقان.

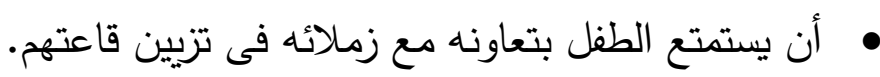
• أن ينظف الطفل قاعته بمشاركة زملائه.

وفيسما يلي نهوذج لبعض جلسات البرناهج :

\begin{tabular}{|c|c|c|c|c|}
\hline الفنيات المستخدمة فى & مدة الجلسة & موضوعات الجلسة & الهدف من الجلسة & رقم الجلسة \\
\hline • • • اللعب الجماعى اللعبز التربوى & 0 ؛ دقيقة & $\begin{array}{c}\text { (سلطة فواكه) } \\
\text { fruits day }\end{array}$ & مهارة العمل الجماعى & الأولى \\
\hline • • • • المناقشية & 0 ؛ دقيقة & (تزيين القاعة) & مهارة العمل الجماعى & الثانية \\
\hline • • • • المناقشية الدبة الدور & دقيقة & نشاط مسرحى (مهنى) & مهارة العمل الجماعى & الثالثة \\
\hline • • لـب اللاور الجماعى & 0 ؛ دقيقة & $\begin{array}{l}\text { five ( نشاط حركى } \\
\text { (little monkeys }\end{array}$ & مالتعاون مـع الزملاء الجماعى & الرابعة \\
\hline
\end{tabular}




\section{المبلة العلمية لكاية رياض الأطفال س جاهمة بوروسعيد}

\section{البلسة الأولى}

عنوان البلسة : مهارة العمل الجماعى والتعاون مع الزملاء

( المشاركة النشطة والفعالة مع الاخرين )

الفئة المستهدفة : أطفال الروضة قاطنى العشوائيات من ( ع-0) سنوات .

$$
\text { زمن البلسة : 0 }
$$

fruits day اسم النشاط : صحى (سلطة فواكه)

الأهداف العامة :

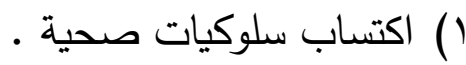

r) تعلم الطفل أهمية التعاون والمشاركة فى العمل .

r) إحساس الطفل بالسعادة لمشاركة زميله له فى اللعب .

الأهداف الإجرائية :

( ) أن يسمى الطفل الفواكه المستخدمة فى النشاط بدون أخطاء. r) أن يشارك الطفل زملائه والدارسة فى إعداد سلطة الفواكه بروح التعاون. r) أن يصنع الطفل سلطة الفواكه بمعاونة معلمته بمهارة. ء) أن يغسل الطفل الفواكه مع أصدقائه بإتقان. الأدوات والروسائل المستفدهة : فواكه طازجة - اوراق كانسون ملونة - شاليموه .

الفنيات الإرشادية المستفدهة :

$$
\text { النمذجة - اللعب الجماعى - التعزيز - اللعب التربوى }
$$

عرض النشاط : (1)

تقوم الدارسة بتهيئة النشاط وتحضر معها مجموعة من الفواكه الطازجة اللذيذة وتعرضها على الأطفال وتطلب منهم تسميتها ثم تقول لهم من يرغب فى تتاول سلطة الفواكه اللذيذة ؟ وتستمع الى اجاباتهم ثم تقول هيا نعمل معا سلطة 


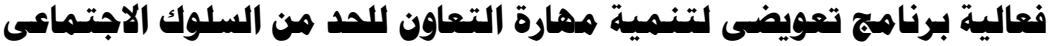

السببى لدى أطفال الروضة قاطني العشوائيات

الفواكه بشرط ان نتعاون معا في صنعها وتقسم الأطفال الى مجموعات مكونة من ثلاث أطفال ، مجموعة مسئولة عن غسل الفواكه جيدا ، ومجموعة أخرى مسئولة عن توزيع الأطباق بعدد الاطفال ، ومجموعة مسئولة عن تقطيع الفواكه بالساكين البلاسـتيكية ، ومجموعـة الأخيرة مسـؤلة عـن تتظيف القاعـة بعـد الانتهاء مـن النشاط على أن يتم فى جو تعاونى مثمر يدرب الأطفال على مهارة التعاون

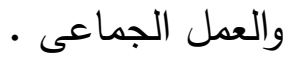

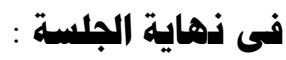

تؤكد الدارسـة علـى أهـداف الجلسـة وهـى تأكيـد على مهـارتى العمـل

الجماعى والتعاون مع الزملاء لتحقيق هدف واحد بنجاح .

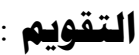

تطلب الدارسة من الأطفال :

() تسمية الفواكه المستخدمة فى النشاط بدون أخطاء .
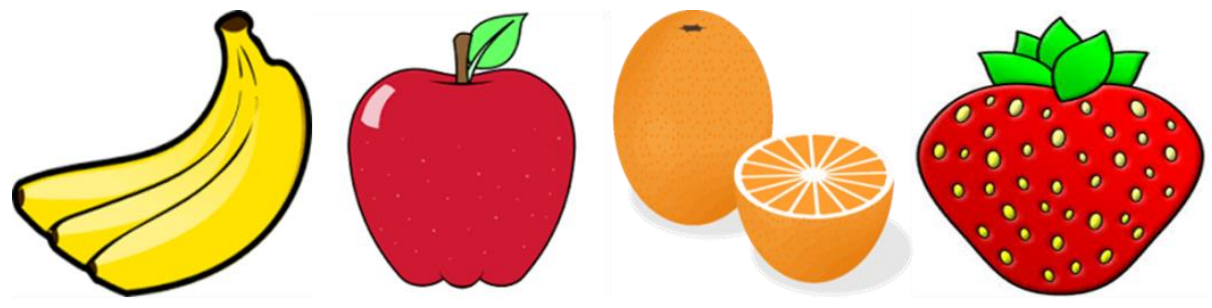

r) تلاحظ الدارسة مدى مشاركة الطفل لها ولزملائه فى إعداد سلطة الفواكه بروح

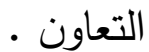

r) عمل سلطة الفواكه بمعاونتها بمهارة . ؟) غسل الفواكه مع أصدقائهم بإتقان . 


\section{البمانة الثثانية}

عنوان البلسة : مهارة العمل الجماعى والتعاون مع الزملاء

$$
\text { ( تقديم المساعدة الآخرين ) }
$$

الفئة المستهدفة : أطفال الروضة قاطنى العشوائيات من ( ع - 0 م ) سنوات .

$$
\text { زمن البلسة : مك ـ دقيقة . }
$$

$$
\text { اسم النشاط : فنى ( تزيين القاعة ) . }
$$

الأهداف العامة :

(1) معرفة الأطفال قيمة وأهمية المشاركة والتعاون .

r) تدريب الأطفال على تحمل مسئولية نظافة الفصل .

r) تدريب الأطفال على الإلتزام بالعمل الموكل له .

الأهداف الإجرائية :

() أن يذكر الطفل اثثان من الأشياء اللازمة لتزيين القاعة بطريقة صحيحة . r) أن يدرك الطفل قيمة النظافة من خلال تزيين قاعته بشكل جمالى . r) أن يستمتع الطفل بتعاونه مع زملائه فى تزيين قاعتهم . ع) أن ينظف الطفل قاعته بمشاركة زملائه . الأدوات والوسائل المستخدهة :

$$
\text { أوراق كانسون ملونة- بالونات - أوراق زينة }
$$

الفنيات الإرشادية المستخدهة :

$$
\text { الحوار والمناقشة - النمذجة - العمل الجماعى - التعزيز }
$$

\section{عرض النشاط : ع}

في هذا النشـاط تتحدث الدارسـة مـع الأطفال عن القاعـة وتسألهم : مـا المسئولية التى تقع علينا تجاه القاعـة التى نوجد فيها ؟ وتترك فرصـة للأطفال 


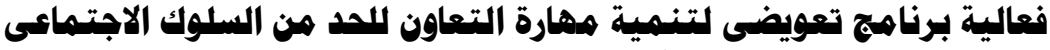 السلبى لدى أطفال الروضة قاطنى العشوائيات}

للحديث ث تتحدث معهم على أن كل طفل مسئول عن القاعة من حيث نظافتها على أن تكون القاعة نظيفة ومرتبة ومنظمـة فهى ليست مسؤلية فرد واحد فقط ولكن مسؤلية الجميع من خلال مشاركتهم سيتحقق هذا الغرض ثم توزع الدارسة الخامات على الأطفال على أن تكون كل مجموعة مسؤلة عن عمل شىء معين كتعليق الزينة أو إزالة القمامة من الأرض أو نفخ البالونات وتعليقها ـ

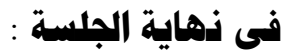

تؤكد الدارسة على أهداف الجلسة وتتناقش مع الأطفال بعد الانتهاء من تزيين القاعـة حول هذا العمل وعن سبب نجاحه وهو مشـاركة وتعاون الجميع لتحقيق نفس الهدف. التقويم :

تطلب الدارسة من الأطفال :

( ) ذكر اثنان من الأشياء اللازمة لتزيين القاعة بطريقة صحيحة . r) وضع دائرة حول صورة السلوك غير الصحيح داخل القاعة .
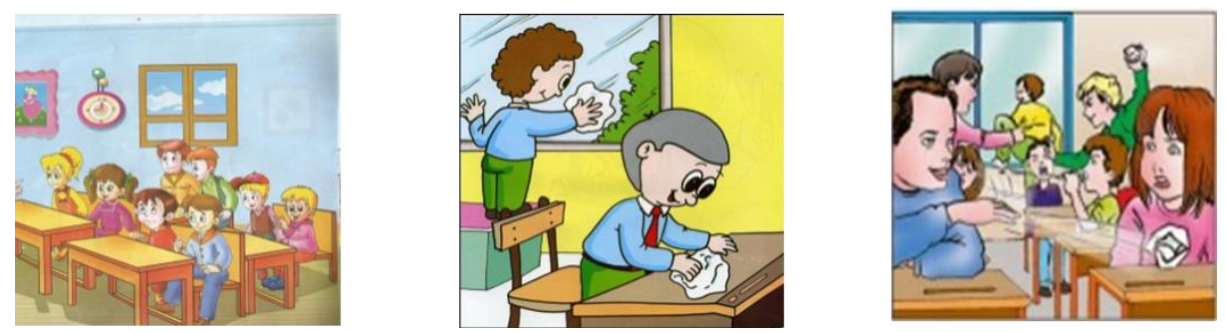

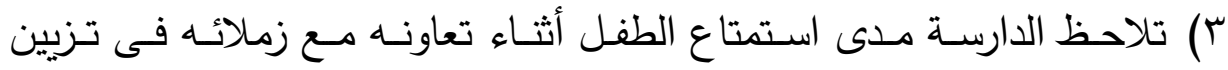
قاعته . - ماع. ع) تنظيف قاعتهم بمشاركة زملائهم . 


\section{المبلة العلمية لكاية رياض الأطفال س جاهمة بوروسعيد}

\section{الجاستة الثثالثة}

عنوان الجلسة : مهارة العمل الجماعى والتعاون مع الزملاء

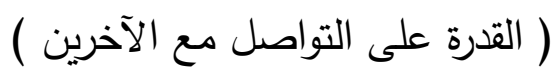

الفئة المستهدفة : أطفال الروضة قاطنى العشوائيات من ( ع-ه) سنوات.

$$
\text { زهن البلسة : 0ك مـ دقيقة . }
$$

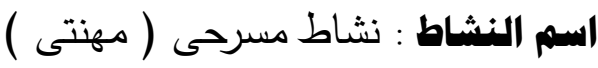
الأهداف العامة :

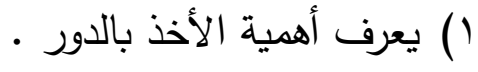

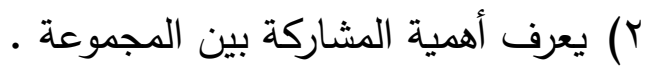

r) يعرف كل طفل مسؤليته نحو المجموعة التى ينتمى إليها .

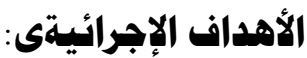

() أن يسـمى الطفـل المهنــة التـى يؤديهــا والأدوات المسـتخدمة فيهـا بطريقــة

$$
\text { صحيحة . }
$$

r) أن يؤدى الطفل النشاط بسعادة مع زملائه . r) أن يمثل الطفل الدور الذى اختاره بمهارة . الأدوات والبوسائل المستخدهة :

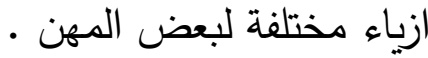

\section{الفنيات الإرشادية المستفدهة :}

$$
\text { الحوار والمناقشة - النمذجة - لعب الدور }
$$

\section{عرض النشاط :}

تتحدث الدارسة مع الأطفال عن المسؤلية وأن كل فرد مسئول عن شىء معين لابد أن يقوم بتتفيذه ، فالطبيب مثلا مسئول عن وصف الدواء للمريض وكن ومسـاعدته على الشـفاء ، والشـرطى مسئول عن حفظ النظام وهكذا ثم تطلب الدارسـة من الأطفال عرض بعض المواقف التى يكون الطفل مسئولا فيها عن سواء فى المنزل أو الروضة ثم تستمع الدارسة لاجاباتهم ثم تحمسهم لأداء النشاط لاط لئ 


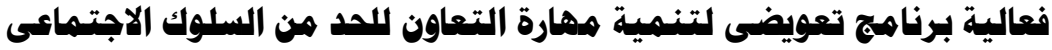

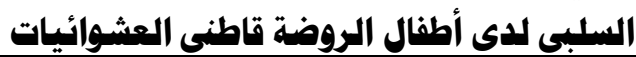

حيث تقوم كل مجموعة باختيار الدور الذى تحب ان تقوم بـه ، على أن تكون

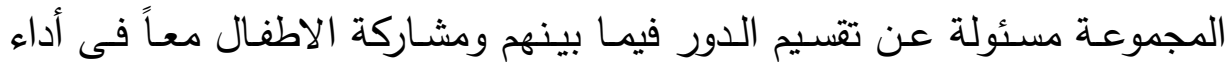
الدور التمثيلى وبعد الانتهاء يكون هناك حواء بين الدارسة والأطفال عن دور كل

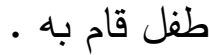

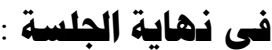

تؤكـد الدارسـة على أهـداف الجلسـة وهـى تأكيد على مهـارتى العمـل

الجماعى والتعاون مع الزملاء لتحقيق هدف واحد بنجاح.

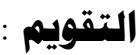

تطلب الدارسة من الأطفال :

() وضع دائرة حول المهنة التى تؤديها وتلوينها
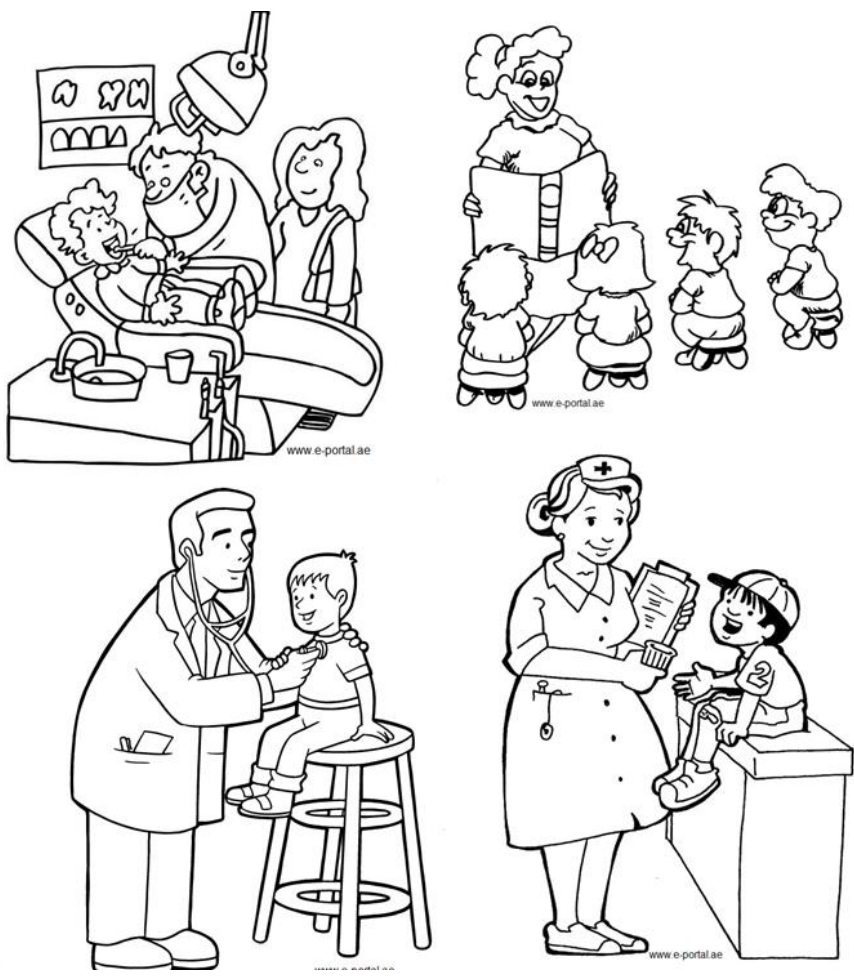

r) توصيل المهنة التى قاموا باختيارها مع الأدوات التى تستخدم بها . 

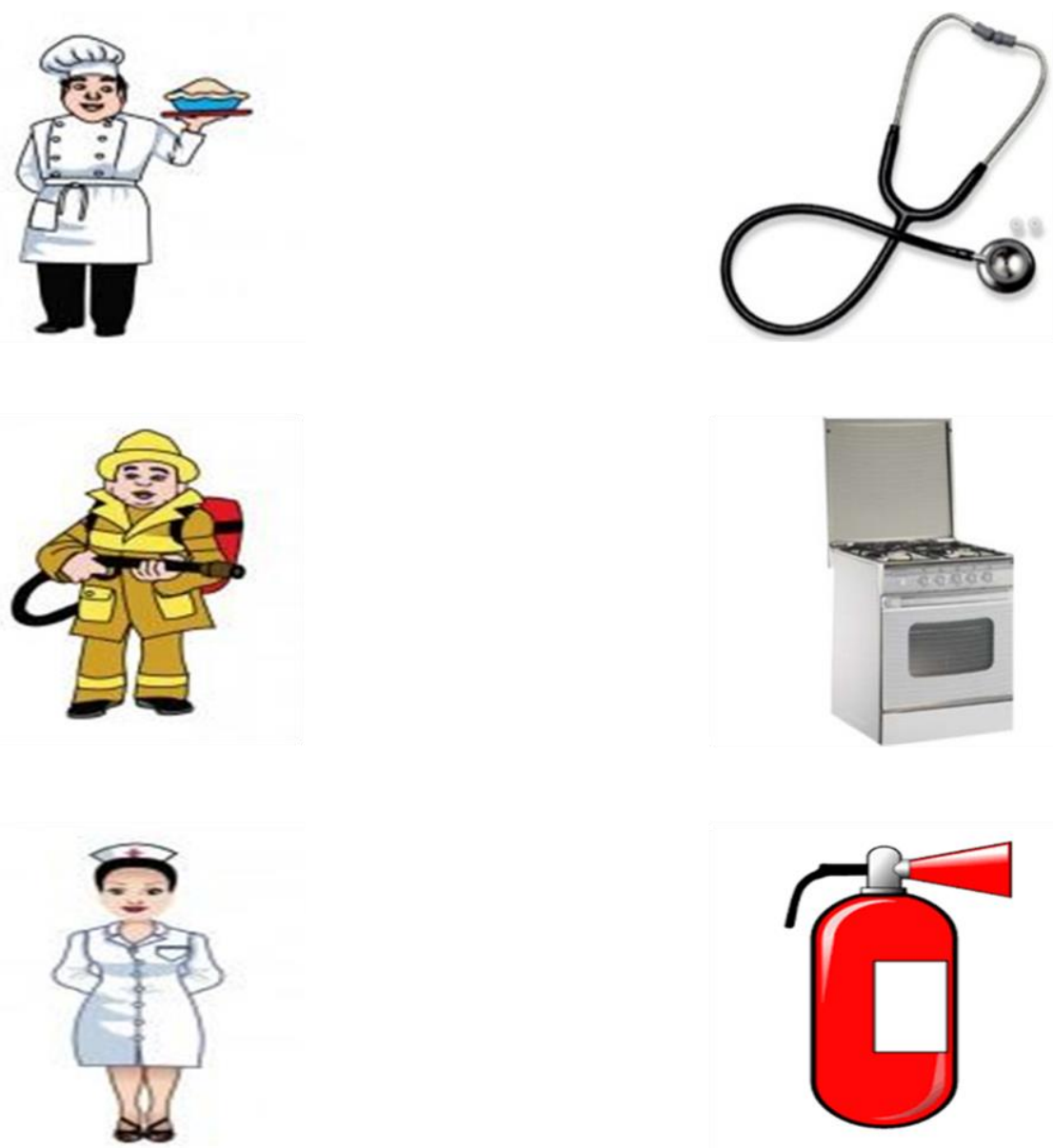

r) تمثيل الدور الذى اختاروا بمهارة . 


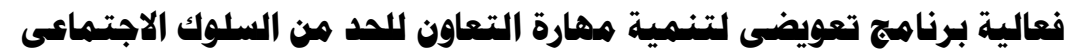
السلبى لدى أطفال الروضة قاطنى العشون التشوائيات

\section{البلسة الثالثة}

عنوان البالسة : مهارة العمل الجماعى والتعاون مع الزملاء ( المشاركة النشطة والفعالة مع الاخرين )

الفئة المستهدفة : أطفال الروضة قاطنى العشوائيات من ( ع-0) سنوات.

زهن البلسة : 0ـ مقيقة .

اسم النشاط : نشاط حركى (five little monkeys) الأهداف العاهة :

( ) معرفة الطفل بمسؤليته نحو المجموعة المنتمى إليها ـ r) إسعاد الأطفال بالنشاط بالألعاب الحركية الجماعية . r) حث الطفل على مشاركة زملاءه في الانشطة والبعد عن الوحدة والعزلة . الأهداف الإجرائية : ( ) أن يذكر الطفل اسم الحيوان الموجود بالاغنية بطريقة صحيحة. r) أن يستمتع الطفل بالنشاط مع زملائه. r) أن يؤدى الطفل الحركات الملائمة للأغنية بمهارة. الأدوات والوسائل المستخدهة :

$$
\text { ماسكات لزى القرود - كمبيوتر • }
$$

الفنيات الإرشادية المستفدهة :

$$
\text { لعب الدور - اللعب الجماعى - النمذجة. }
$$

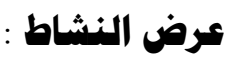

تقوم الدارسة بتشغيل الأغنية للأطفال وتعرضها لهم من خلال الكمبيوتر

ثم تقوم بتقليد حركات القرود فى الاغنية وتدربهم عليها ثم تقوم باختيار ( ) أطفال وتلبسـهم زى القرود وتطلب منهم التعاون فيما بينهم للرقص على نغمات

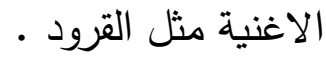




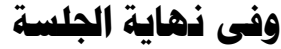

تؤكـد الدارسـة على أهـداف الجلسـة وهـى تأكيـد على مهـارتى العمـل الجماعى والتعاون مع الزملاء لتحقيق هدف واحد بنجاح وهو التعاون فى اخراج

الرقصة بشكل جميل - الر ل

التقويم :

تطلب الدارسة من الأطفال :

( ) ذكر اسم الحيوان الموجود بالاغنية بطريقة صحيحة .
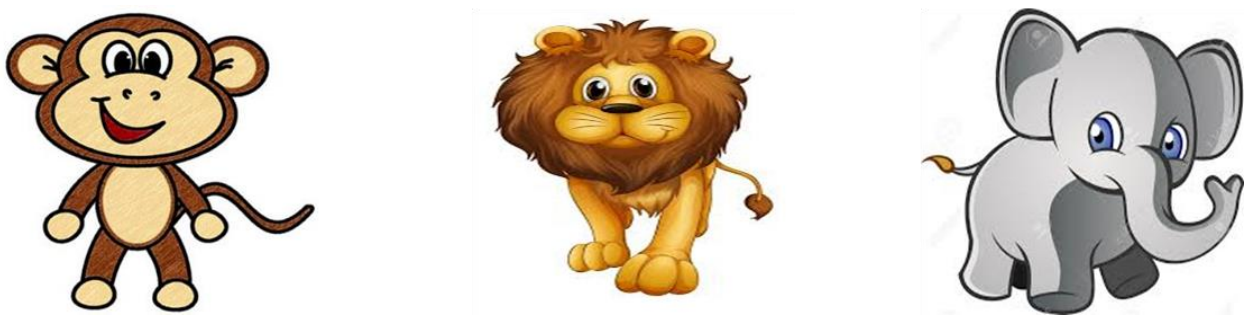

r) تلاحظ الدارسة مدى استمتاع الطفل بالنشاط مع زملائه . r) تأدية الحركات الملائمة للأغنية بمهارة .

نتائج الدراسة : ناديه

نتــائج الفــرض الأول : يـص الفرض الأول علي أنـه "توجد فروق ذات دلالـة إحصـائية بـين متوسطي رتب درجـات أطفـال الروضــة قـاطنى العشـوائيات بـين التطبيق القبلى والبعدى على مقياس مهارة التعاون لصالح التطبيق البعدى". وللتحقق من صحة هذا الفرض، تمت مقارنـة متوسط رتب درجات عينة

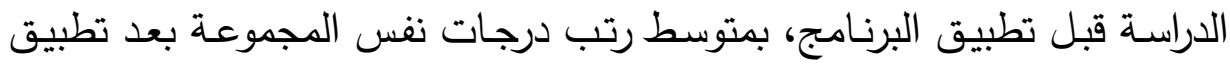
البرنامج ، علي مقياس مهارة التعاون المستخدم في الدراسة الحالية ، وتم استخدام

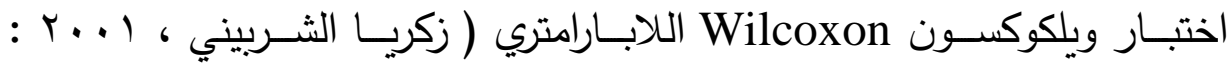

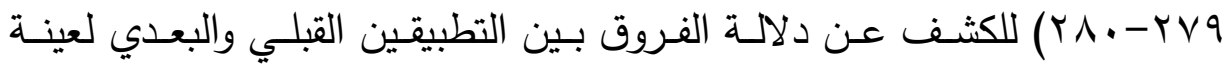
الدراسة ، ويوضح جدول رقم (1) ما توصلت إليه النتائج : جدول رقم (1) 


\begin{tabular}{|c|c|c|c|c|c|c|}
\hline \multicolumn{7}{|c|}{ 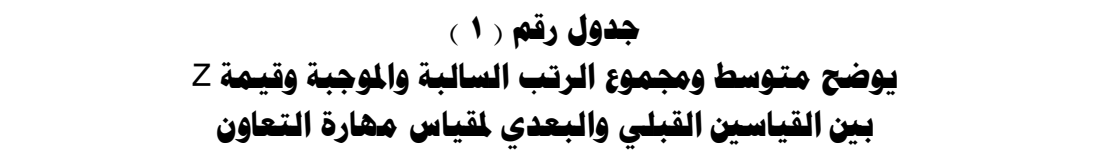 } \\
\hline \multirow{2}{*}{ دلالتها } & \multirow{2}{*}{ قيمة z } & \multicolumn{2}{|c|}{ القياس القبلي / البعدي } & \multirow{2}{*}{ العدد } & \multirow{2}{*}{ المتغير } & \multirow{2}{*}{ الابعاد } \\
\hline & & مجموع الرتب & متوسط الرتب & & & \\
\hline \multirow{4}{*}{ •, } & \multirow{4}{*}{$1, \wedge \leq 1-$} & $\cdot, \cdots$ & $\cdot, \cdots$ & $\cdot$ & الرتب السالبة & \multirow{4}{*}{ مهارة التعاون } \\
\hline & & $1 \cdot, \cdots$ & Y,O. & $\xi$ & الرتب الموجبة & \\
\hline & & & & 11 & الرتب المحايدة & \\
\hline & & & & 10 & المجموع الكلي & \\
\hline \multirow{4}{*}{$\cdot, \ldots$} & \multirow{4}{*}{$r, \leqslant 10-$} & $\cdot, \cdots$ & $\cdot, \cdots$ & $\cdot$ & الرتب السالبة & \multirow{4}{*}{ للارجة الكلية } \\
\hline & & Ir., & $\Lambda, \cdots$ & 10 & الرتب الموجبة & \\
\hline & & & & - & الرتب المحايدة & \\
\hline & & & & 10 & المجموع الكلي & \\
\hline
\end{tabular}

يتضح من الجدول السابق وجود فروق ذات دلالة إحصسائية عند مستوي

دلالة (7 ا • . • ) بين متوسط رتب درجات الأطفال قاطني العشوائيات أفراد عينة الدراسـة قبـل وبعد تطبيـق البرنـامج في البُعد الرابع علي مقيـاس مهارة التعـاون المصور المستخدم في الدراسة الحالية ، لصالح التطبيق البعدي ، وبلغت قيم

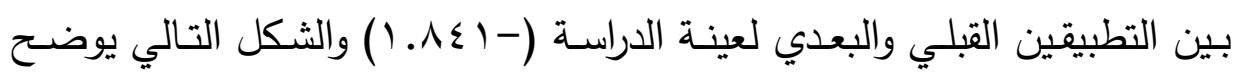
ذزلك

شكل رقم ( 1 ) يوضح الفرق بين التطبيقين القبلي والبعدي علي هقيساس ههارة التعاون

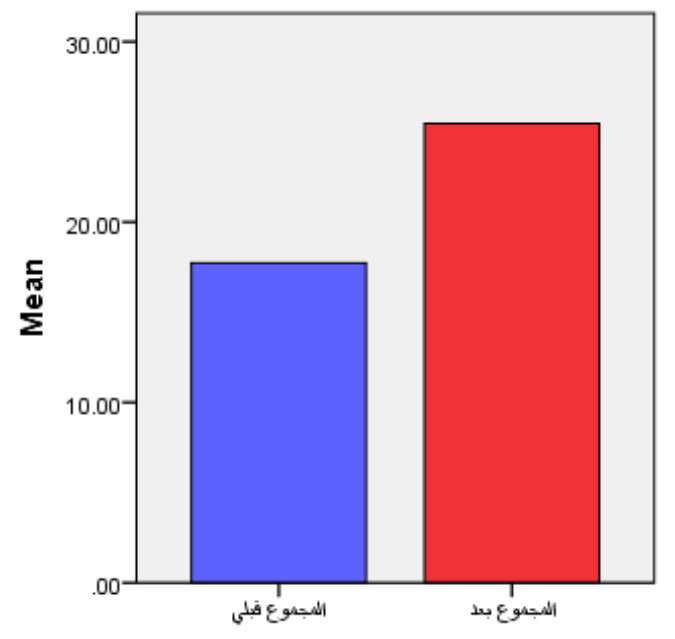


يتضـح من الشكل السابق وجود فروق ذات دلالة إحصائية عند مستوي دلالة ( ( . . • ) بين متوسط رتب درجات الأطفال قاطني العشوائيات أفراد عينة الدراسـة قبل وبعد تطبيق البرنـامج في علي مقياس مهارة التعاون المصور ككل المسـتخدم في الدراسـة الحاليـة، لصـالح التطبيـق البعـدي، وبلغـت قيم Z بـين التطبيقين القبلي والبعدي لعينة الدراسة علي مقياس مهارة التعاون (-0 (ـ.ب) ، مما يدل علي تحقق الفرض الأول للدراسة في مقياس مهارة التعاون المستخدم في الدراسة الحالية . الد

\section{تشفير نتالُه الفرض الأول :}

تؤكــــت نتيجـة الفـرض الأول علـى أن أنشــة البرنــامج التعويضـى تـم

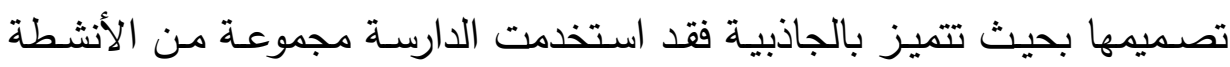
المختلفة، وأن الفنيات والوسائل المستخدمة بالبرنامج كانت مناسبة للطفل وكذلك الاسـتراتيجيات المتبعـة في التقويم مـن تصـحيح لـلاداء وتشـجيع على النجـاح والتكرار ، وكل هذه العوامل مجتمعـة اسـهت في ان يؤدي الطفل الذى يصدر عنه سلوك غير مقبول اجتماعياً بتعديل سلوكياته السلبية غير المقبولة نحو البيئة والأشخاص ويصبح أكثر تعاونـاً فى أداء المهام المطلوبـة منـه ، وهذا مـا أكدته فئه

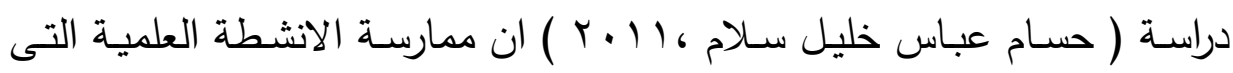
يتضمنها البرنامج أتاحت الفرصة للأطفال للتعاون والتفاعل الإيجابى بينهم وكذلك

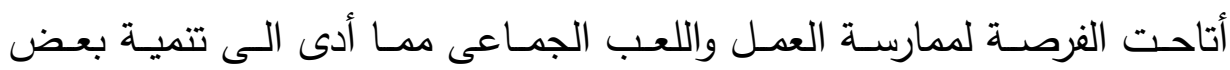
المهارات الاجتماعية ومن خلال ملاحظة الباحث للأطفال وتوجيهـي لإتباع أنماط بـاط • السلوك الاجتماعى السليم نتائج الفرض الثانى : ينص الفرض الثانى علي أنه " لا توجد فروق ذات دلالة احصائية بين متوسطات رتب درجات الأطفال قاطنى العشوائيات بين التطبيق البعدى والتتبعى على بطاقة ملاحظة السلوك الاجتماعى السلبى " . وللتحقق من صحة هذا الفرض ، تمت مقارنة متوسط رتب درجات عينة الدراسة بعد تطبيق البرنامج ، بمتوسط رتب درجات نفس المجموعة بعد شهر من 


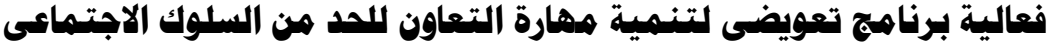

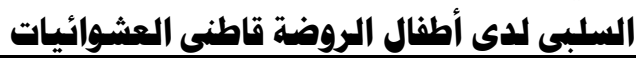

الاختبار البعدي ، في الدرجة الكلية بطاقة ملاحظة السلوك الاجتمـاعى السلبى

Wilcoxon المسـخدم في الدراسـة الحاليـة ، وتم استخدام اختبـار ويلكوكسـونه اللابـارامتري للكثـف عـن دلالــة الفـروق بـين التطبيقين البعدي والتتبعي لعينـة

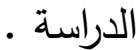

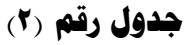

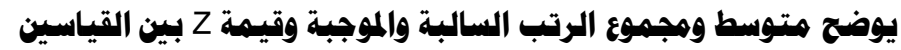

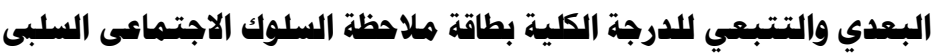

\begin{tabular}{|c|c|c|c|c|c|}
\hline \multirow{2}{*}{ دلالتها } & \multirow{2}{*}{ قيمة z } & \multicolumn{2}{|c|}{ العياس البعدي/التبعي } & \multirow{2}{*}{ العدد (ن) } & المتغير \\
\hline & & مجموع الرتب & متوسط الرتب & & بطاقه ملاحظه السلوك \\
\hline \multirow{4}{*}{ 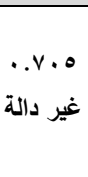 } & \multirow{4}{*}{. rVvA- } & T1... & $\xi \ldots$ & T & الرتب السالبه \\
\hline & & 19. & $\varepsilon .$. & $\xi$ & الرتب الموجبه \\
\hline & & & & $\Lambda$ & الرتب المحايدة \\
\hline & & & & 10 & المجموع الكلي \\
\hline
\end{tabular}

يتضـح من الجدول السـابق عدم وجود فروق ذات دلالمة إحصـائية عند

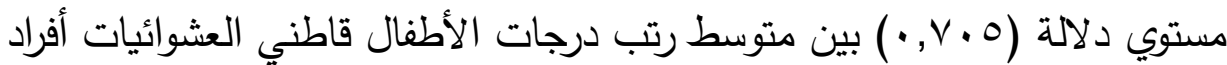
عينـة الدراسـة بعد تطبيق البرنـامج ودرجـاتهم في التطبيق التتبعي علـي بطاقة ملاحظة السلوك الاجتماعى السلبى المستخدم في الدراسـة الحالية ، وبلغت قيم

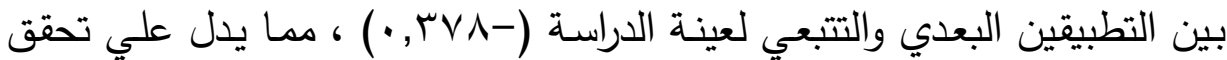

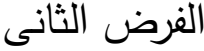

يوضح الفرق بين التطبيقين البعدي والتتبعي علئ بطاقة هلاحظة السلوك الاجتهاءى السلبى

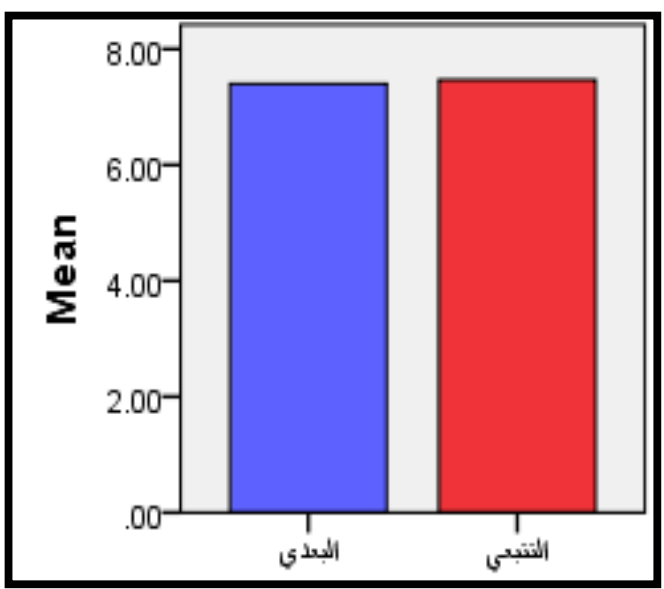




\section{تفنسير نتانجه الفرض الثانى :}

وتعزو الدارسة استمرار ثبات انخفاض السلوك الاجتماعى السلبى خلال

فترة المتابعة الى ميل الاطفال الى تكرار السلوكيات الإيجابية حيث أكدت مختلف البحوث والدراسـات أن المنـاطق العشـوائية تتميز بمظـاهر التفكلك فى العلاقـات الاجتماعية يصعب معه توافر نماذج سلوكية وثقافية سوية يمكن للطفل تقليدها، وهذا ما أكدت عليه دراسـة ( مريم احمد مصطفى ، 99 V 199 ) أن أهم المشكلات الاجتماعية والثقافية فى المناطق العشوائية هى مشكلة التزاحم وارتفاع الكثافة

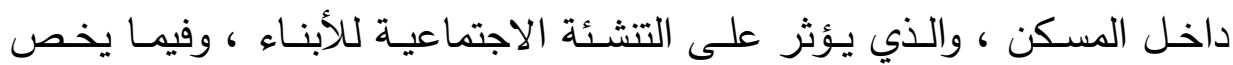
المشكلات الأسـرية، إلى ارتفـاع نسبة المشكلات بـين الأزواج ، وعن أسـاليب التشئة الاجتماعية داخل الأسرة فإن طابع العنف والقسوة كان هو المسيطر على الى التى عملية التشتئة إلى حد كبير ، وبالتالى ينتج عن الطفل سلوكيات تتعارض مـع القيم والمعايير الاجتماعية والثقافية السائدة فى المجتمع ، ونتيجة تعزيز سلوكيات الطفل الجديدة المتعلمة المقبولة فى المجتمع سعى نحو استمرارها حتى يلقى إثابة

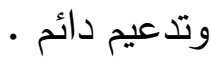

\section{قاتُمة الدراجمج}

\section{أولاً : المراجع العربية}

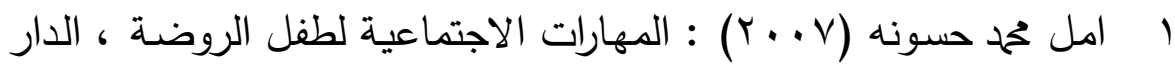

$$
\text { العالمية للنشر والتوزيع ، القاهرة . }
$$

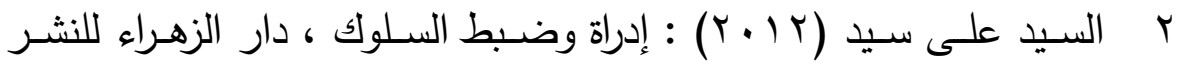
والتوزيع، الرياض ، المملكة العربية السعودية . r م السـيد محم أبـو هاشـم (ع . . r) : سـيكولوجية المهـارات ، مكتبـة زهـراء

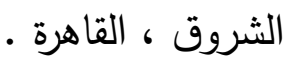




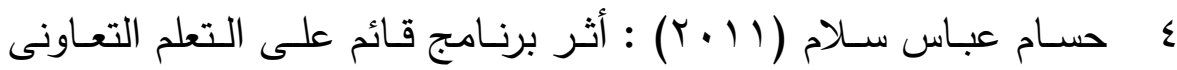

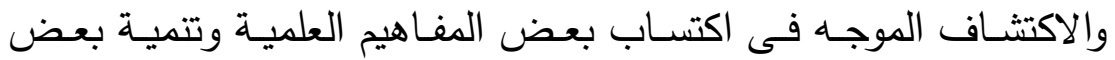
المهـارات الاجتماعيـة لـدى الموهـوبين ذوى صـعوبات الـتعلم بريـاض الأطفــال ، مجلــة الطفولـة والتربيـة ، كليـة ريـاض الأطفـال ، جامعــة الأسكندرية ، العدد الثامن ، الجزء الثانى ، السنة الثالثة ، سبتمبر •

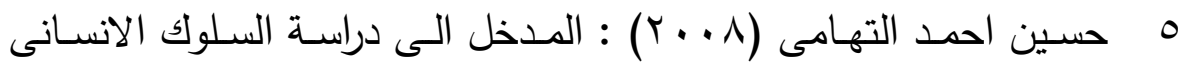
مقدمة فى العلوم السلوكية ، الدار العالمية للنشر والتوزيع ، الجيزة . 7 حمدى محمد منصور (1991) : علاقة بعض المتغيرات الأسرية بالسلوك الاجتمـاعى لطفل الحضـانة كمؤشرات لتحديد دور أخصـائى خدمة الفرد فى مرحلة ماقبل المدرسة ، المؤتمر العلمى الخامس للخدمة الاجتماعية ، كلية الخدمة الاجتماعية ، جامعة حلوان • خيـر الدين علي عـويس (999 ( ) : دليـل البحث العلمي ، دار الفكـر

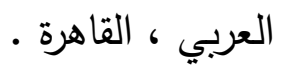

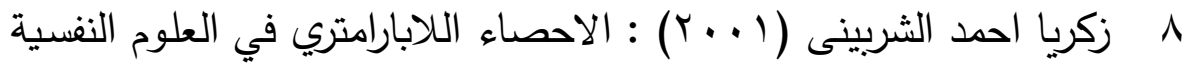
والتربوية والاجتماعية مع استخدام SPSS ، الأنجلو المصرية ، القاهرة . 9 سامى عبد السميع نور الدين (1994) : التشئية الاجتماعية فى المناطق الحضرية المحرومة ، دراسة انثروبولوجية التربية لمنشأة ناصر بالقاهرة ، رسالة ماجستير غير منشورة ، كلية التربية ، جامعة عين شمس •

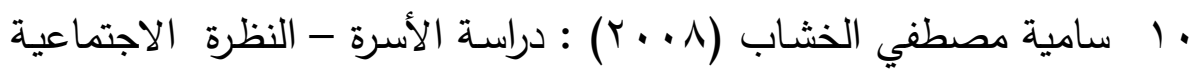
مكتبة النصر ، جامعة القاهرة .

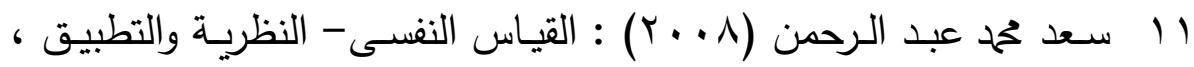




\section{الجلة العلمية لكلية رياض الأطفال = جاهعة بوريسيد}

ط ه ، هبة النيل العربية للنشر والتوزيع ، الجيزة .

r أ سناء حسنين الخولى (Y99 ()) : الأسرة والمجتمع ، دار المعرفة الجامعية

$$
\text { الاسكندرية . }
$$

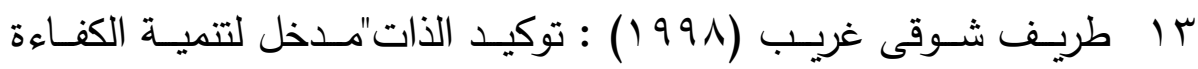
الشخصية " ، دار غريب ، القاهرة .

ع ا عـادل عـازر وناهد رمـزى (1991) : ظـاهرة عمالـة الأطفال ، المركز القومى للبحوث الاجتماعية والجنائية ، القاهرة . 10

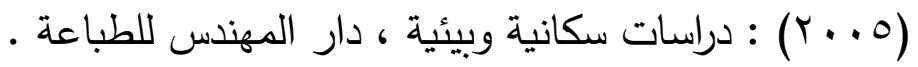
17 المنـاطق العشـوائية ، المركـز القـومى للبحـوث الاجتماعيـة والجنائيـة ،

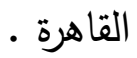
IV عـلا مصطفى أنور (1991) : ظـروف الأطفال وأوضـاعهم فى بعض المنـاطق العشـوائية ، المركـز القـومى للبحـوث الاجتماعيـة والجنائيـة ،

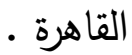

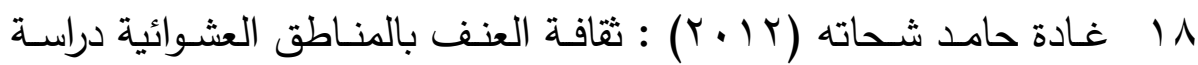
حالة ، دار الفكر العربى، القاهرة . 9 1 19 العربى للنشر والتوزيع ، القاهرة .

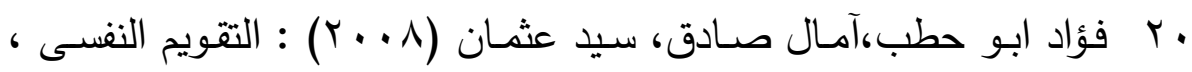
مكتبة الأنجلو المصرية ، القاهرة . ا Y فؤاد البهى السيد (1911) : علم نفس الاجتمـاعى ، طب ، دار الفكر 


\section{فعالية برناهج تعويضى لتنهية ههارة التعاون للحد هن السلوك الاجتهاءى العائي

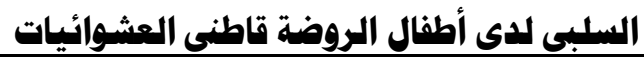

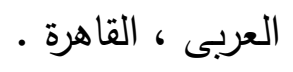

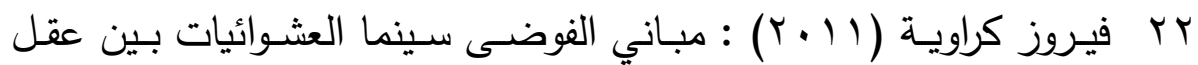
طبقة وعقل نظام ، مكتبة مدبولي ، القاهرة .

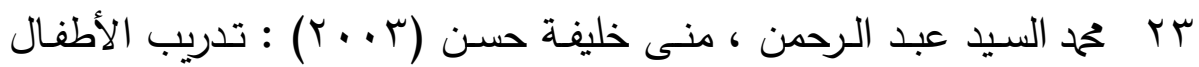
ذوى الاضطرابات السلوكية على المهارات النمائية دليل الآباء والمعالجين

$$
\text { دار الفكر العربى ، القاهرة . }
$$

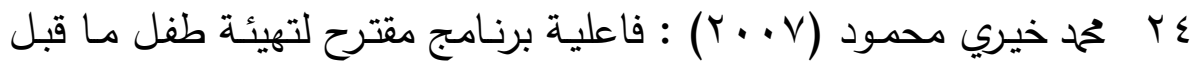

المدرسة وتتمية قدراته على التفكير واتجاهه لمواجهه التغيرات المستقبلية ،

المؤتمر العلمي السنوي (9 (1) أبريل ، مركز الكتاب للنشر والتوزيع ،

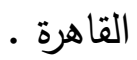

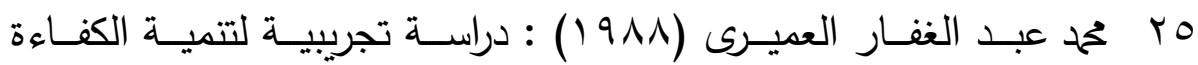
الاجتماعيـة لـى طـلاب الجامعـة ، رسـالة دكتوراه غير منشـورة ، كليـة التربية ، جامعة عين شمس ·

דr مريم أحمد مصطفى (99V 19) : الخصائص الاجتماعية والثقافية للمناطق العشوائية ، دار المعرفة الجامعية ، الاسكندرية .

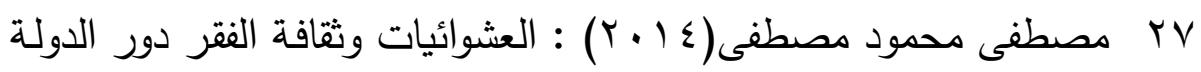
وآليات المواجهة ، طن ، مصر العربية للنشر والتوزيع ، القاهرة .

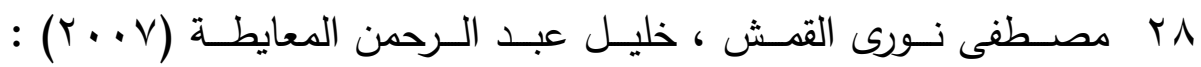
الاضطرابات السلوكية والانفعالية ، دار الميسرة للنشر والتوزيع ، عمان . 9 ب معتز سيد عبد الله (1991) : إدراك المخاطر والمشكلات البيئية لسكان حى شعبى بمدينة القاهرة ، المركز القومى للبحوث الاجتماعية والجنائية ، القاهرة . - ماه 
•r معـن خليـل عمـر (1999) : البنـاء الاجتمـاعى وأنسـاقه ونظمـهـ ، دار الثروق للنشر والتوزيع ، الأردن •

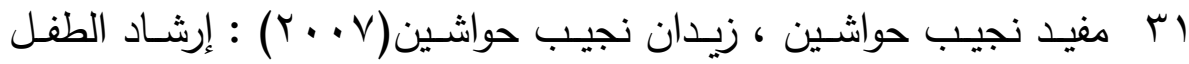
وتوجيهه ، طس ، دار الفكر ناشرون وموزعون ، عمان •

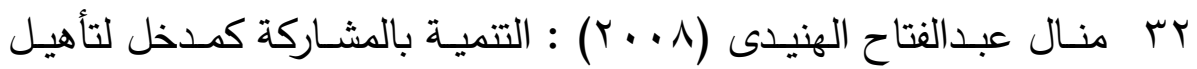
وتدريب معلمات الروضة غير المؤهلات فى المناطق العشوائية فى مجال منـاهج وطرق تدريس التربية الفنية ،المجلة العلميـة المتخصصـة لمعهد دراسـات الطفولة ، جامعة عين شمس ، المجلد اله العددمب ، يناير -

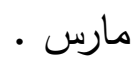
بr منى اسماعيل احمد (T ץ) : استخدام استراتيجية التعلم التعاونى في تتمية المهارات اللغوية والإجتماعية لطفل الروضة ، رسالة دكتوراه ، كلية رياض الأطفال ، جامعة القاهرة .

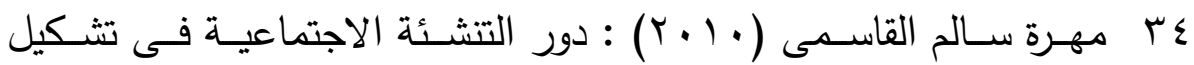
السلوك السوى للأبناء ، دار الفكر العربى ، القاهرة .

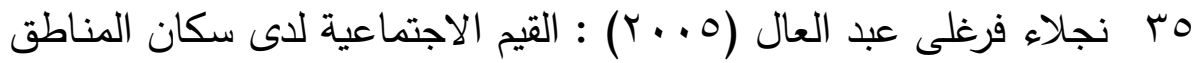
العشوائية دراسة ميدانية على منطقة الزاز بمنشأة ناصر ، رسالة ماجستير جامعة القاهرة ، كلية الآداب ، قسم الاجتماع •

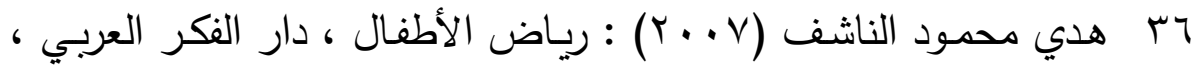

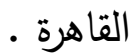

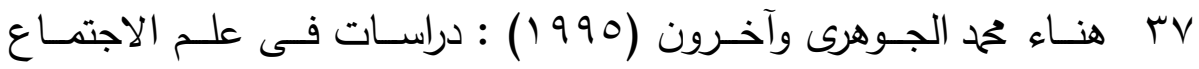

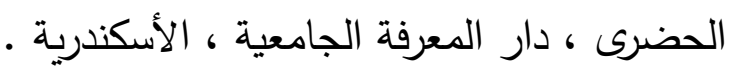

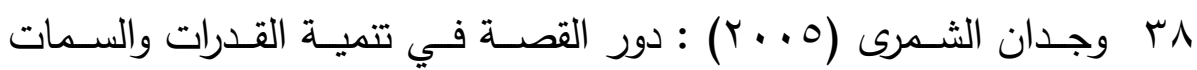
الإبداعية لاى طفل الروضة ، الدار العالمية للنشر والتوزيع ، القاهرة . 


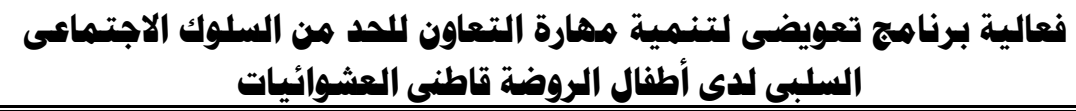

ثانيكا : المراجع الأجنبية :

39 Abate, L.L. \& Milan, M. A.(1985):Handbook Of Social Skills Training and Research, Awiley-Inter Scince Publication, John Wiley \& sons, NEW YORK, Chichester.

40 Merrell, K, W. (1998) : Assessing social skills and peer relations (L)H. Booney Vance (ed) Psychological Assessment of children. New York: John Wiley \& Sons Inc.

41 Taylor, Erin B, fromel campo to El Barrio (2009): Memory and Social Imaginaries in santo Domingo, Vol.16 Issue.2 ,mar/ apr.

42 Varma,V.(1997):Troubles Of Children and Adolescents, Jessica Kingsley, Publishers, London \& Bristol, Pennsylvania.

43 Weaver-Zercher, Valerie (2008): Christian Century, the Gospel of Gather Joe: Revaluations and Revaluations in the slums of Bangkok, Vol. 125 Issue 21. 